\title{
The Search for Better Communication Between the Debt Collector and the Consumer Under the Fair Debt Collection Practices Act
}

\author{
Elwin Griffith $^{*}$
}

I. INTRODUCTION

After Congress passed the Fair Debt Collection Practices Act (FDCPA $),{ }^{1}$ debt collectors no longer had free rein to do as they pleased. It was a serious turn of events because until then many states had no effective laws to control the conduct of collectors. ${ }^{2}$ It was not unusual, therefore, to find debt collectors routinely harassing and deceiving consumers during the collection process. $^{3}$ As a result, the FDCPA

Tallahassee Alumni Professor of Law, Florida State University College of Law. LL.M. 1964, New York University; J.D. 1963, Brooklyn Law School; B.A. 1960, Long Island University.

1. Fair Debt Collection Practices Act, Pub. L. No. 95-109, 91 Stat. 874 (1977) (codified as amended at 15 U.S.C. §§ 1692-1692p (2006 \& Supp. IV 2010)).

2. The Senate Report on the FDCPA gave some idea of the need for debt collection legislation:

[W]hile 37 States and the District of Columbia do have laws regulating debt collectors, only a small number are comprehensive statutes which provide a civil remedy. As an example of ineffective State laws, of the 16 states which regulate by debt collection boards, 12 require by law that a majority of the board be comprised of debt collectors.

S. REP. No. 95-382, at 2 (1977), reprinted in 1977 U.S.C.C.A.N. 1695, 1697.

3. The congressional hearings on the FDCPA produced many examples of consumers' experiences in the marketplace. One witness observed as follows:

While debt collection agencies generate numbers of complaints disproportionate to their size in the American economy, the most disturbing aspect of consumer grievances generated by collection agencies is the type of conduct which is complained about. This conduct ranges from profanity and obscenity in phone calls to efforts to shame a consumer by contacting relatives, employers, neighbors to falsely threatening to seek harsh legal sanctions.

Fair Debt Collection Practices Act: Hearings on S. 656, S. 918, S. 1130 and H.R. 5294 Before the Subcomm. on Consumer Affairs of the S. Comm. on Banking, Housing and Urban Affairs, 95th Cong. 85 (1977) (statement of Robert J. Hobbs, Staff Attorney, National Consumer Law Center). During the hearings, another witness indicated that his research showed that collectors justified their harsh collection methods on the basis of the consumer's status as a "deadbeat." Id. at 237 (testimony of David Caplovitz, Professor of Sociology, Graduate School of the City of New York). However, Professor Caplovitz explained the real reason for a consumer's default this way:

[T] he collection industry's image of the default debtor as a deadbeat is a grotesque caricature that has virtually nothing to do with the realities of why debtors default .... If 
introduced new restraints on collectors that covered a wide span of activity.

One provision that has received significant judicial attention forbids a debt collector from using "any false, deceptive, or misleading representation or means in connection with the collection of any debt." 4 Although this restriction seems broad, § 1692e lists sixteen examples of specific violations without limiting the general application of the introductory language concerning false, deceptive, or misleading representations. $^{5}$ Because the sixteen examples are not exhaustive, a collector may violate the statute even though its conduct does not fall within any of the specifically enumerated violations. ${ }^{6}$

Section 1692e(3) prohibits the false representation that a collector's communication is from an attorney. ${ }^{7}$ This provision has attracted attention because consumers frequently complain that a collection letter on law firm letterhead has misled them into thinking that an attorney has given such a letter her full attention and that litigation may be imminent. ${ }^{8}$ Naturally, a collector wants to convey the impression to the consumer that an attorney has authored the collection message because it lends an air of seriousness to the communication. The consumer probably knows

either his willingness to pay or his ability to pay is undermined, the credit transaction breaks down and the debtor defaults .... People lose their jobs or are laid off, or they become ill and are unable to work. My research has shown that sudden losses of income are by far the major reason why debtors default on their credit obligations.

Id. at 238 (testimony of David Caplovitz, Professor of Sociology, Graduate School of the City of New York).

4. 15 U.S.C. $§ 1692$ e (2006). This section is but a small part of the overall picture. In 2010, the Federal Trade Commission (FTC) received 108,997 complaints about third-party collectors, around half of which dealt with repeated calls from such collectors. See 2011 FTC ANNUAL REPORT: FAIR DEBT COLLECTION PRACTICES ACT 5.

5. The introductory language of $\S 1692$ e reads as follows: "A debt collector may not use any false, deceptive, or misleading representation or means in connection with the collection of any debt. Without limiting the general application of the foregoing, the following conduct is a violation of this section . . ..” 15 U.S.C. § 1692e.

6. See Lesher v. Law Offices of Mitchell N. Kay, PC, 650 F.3d 993, 997 (3d Cir. 2011) (finding that " $[\mathrm{t}]$ he sixteen subsections of section 1692e set forth a nonexhaustive list of practices that fall within [the] ban”); Clomon v. Jackson, 988 F.2d 1314, 1318 (2d Cir. 1993) (finding that because the $\S 1692 \mathrm{e}$ list is nonexhaustive, a collection practice can be false, deceptive, or misleading even if it does not fall within any of the subsections of § 1692e); Chalik v. Westport Recovery Corp., 677 F. Supp. 2d 1322, 1330 (S.D. Fla. 2009) (stating that "[t]he subsections of 15 U.S.C. § 1692e . . . are a non-exhaustive list of examples of the type of conduct prohibited by the FDCPA”).

7. 15 U.S.C § 1692e(3).

8. See Greco v. Trauner, Cohen \& Thomas, L.L.P., 412 F.3d 360, 362 (2d Cir. 2005); Taylor v. Perrin, Landry, deLaunay \& Durand, 103 F.3d 1232, 1236-37 (5th Cir. 1997); Clomon, 988 F.2d at 1317; Nichols v. Frederick J. Hanna \& Assocs., 760 F. Supp. 2d 275, 277 (N.D.N.Y. 2011); Kelly v. Wolfpoff \& Abramson, L.L.P., 634 F. Supp. 2d 1202, 1205 (D. Colo. 2008). 
that an attorney can take certain legal action that is not available to a lay collector, and therefore any implication of attorney involvement may intimidate the consumer. The prohibition against a false representation of attorney involvement is intended to protect the consumer in this situation. Some collectors, in an attempt to avoid the false representation label, include a clause in the collection letter indicating that no attorney has personally reviewed the consumer's case. ${ }^{9}$ This Article discusses the role of such a disclaimer when a court has to decide whether a collector has made a false representation.

Even if a collector makes such a representation, it violates the statute only if it does so "in connection with the collection of any debt."10 There are frequent disagreements about whether a consumer has established the necessary connection when the collector makes certain overtures to the consumer, sometimes without actually demanding payment. ${ }^{11}$ The answer usually depends on the context of the communication and the nature of the contact between the parties. The mere fact that the parties have established a relationship does not mean that every subsequent communication between them is in connection with collection of a debt. The link may be questionable, especially if the consumer initiates the subsequent contact. ${ }^{12}$ This Article explores what courts look for in

9. See, e.g., Lesher, $650 \mathrm{~F} .3 \mathrm{~d}$ at 1003 (finding that disclaimers on the back of collection letters did not make clear to the least sophisticated consumer that the law firm was acting solely as a collector and not in any legal capacity); Gonzalez v. Kay, 577 F.3d 600, 607 (5th Cir. 2009) (finding that the disclaimer on the back of the collection letter contradicted the language on the front, and that the district court erred in dismissing the consumer's complaint); Greco, 412 F.3d at 365 (holding that, by including disclaimer in collection letter, defendant did not make any false, deceptive, or misleading representation of attorney involvement); Dunn v. Derrick E. McGavic, P.C., 653 F. Supp. 2d 1109, 1113-14 (D. Or. 2009) (finding that collection letter violated the FDCPA because the collection language contradicted the disclaimer).

10. 15 U.S.C. § 1692e.

11. See Grden v. Leiken Ingber \& Winters PC, 643 F.3d 169, 173 (6th Cir. 2011) (finding that ledger sent in response to debtor's call was not in connection with collection of the debt); Gburek v. Litton Servicing LP, 614 F.3d 380, 386 (7th Cir. 2010) (finding that purpose of company's letter was to get the mortgagor to discuss debt settlement options, thus creating a communication in connection with collection of a debt); Ruth v. Triumph P'ships, 577 F.3d 790, 798-99 (7th Cir. 2009) (holding a reasonable trier of fact could conclude that a privacy notice sent in same envelope as collection letter was sent in connection with collection of debt).

12. In Grden, the debtor contacted the collector about the amount due after the collector initiated its lawsuit. 643 F.3d at 173 . The collector responded by sending a ledger statement containing an incorrect amount. Id. at 172-73. Applying an objective standard, the court found that the ledger correspondence did not take place in connection with collection of the debt because the collector's attempt to collect the debt was independent of the consumer's inquiry. Id. at 173. The consumer failed to convince the court that there was a connection because his relationship with the collector arose only because of an outstanding debt. See id. 
determining whether a consumer has established the necessary connection.

Although the FDCPA forbids false representations in connection with collection of a debt, there is a split in the federal circuits over whether such representations include communications to a consumer's attorney. The Third Circuit ${ }^{13}$ and the Fourth Circuit ${ }^{14}$ have rejected the Ninth Circuit's ${ }^{15}$ position that the statute does not cover a collector's false representations to a consumer's attorney. As if this were not enough, the Seventh Circuit ${ }^{16}$ has applied the false representation rule to a collector's communications with the consumer's attorney, but introduced the additional element that any alleged violation should be considered from the perspective of a competent attorney, rather than that of an unsophisticated consumer. ${ }^{17}$ The theory is that if a collector's representation does not mislead a competent attorney, then a collector should have no liability because an attorney acts as an intermediary to protect the consumer from a collector's doings. ${ }^{18}$ This Article reviews the cases, addresses the different approaches that courts have taken to communications with a consumer's attorney, and questions whether a collector should be absolved of liability for a violation in this context.

\footnotetext{
13. Allen ex rel. Martin v. LaSalle Bank, 629 F.3d 364, 368 (3d Cir. 2011).

14. Sayyed v. Wolpoff \& Abramson, 485 F.3d 226, 230 (4th Cir. 2007).

15. Guerrero v. RJM Acquisitions LLC, 499 F.3d 926, 939 (9th Cir. 2007) (per curiam).

16. Evory v. RJM Acquisitions Funding L.L.C., 505 F.3d 769, 775 (7th Cir. 2007).

17. Most courts apply the "least sophisticated consumer" test in determining whether a statutory violation has occurred, the purpose being to protect "the gullible as well as the shrewd." Clomon v. Jackson, 988 F.2d 1314, 1318 (2d Cir. 1993). In this way, the test "ensures the protection of all consumers, even the naïve and the trusting, against deceptive debt collection practices, and ... protects debt collectors against liability for bizarre or idiosyncratic interpretations of collection notices.” Id. at 1320; see also Donohue v. Quick Collect, Inc., 592 F.3d 1027, 1030 (9th Cir. 2010) (noting the least sophisticated consumer standard); Rosenau v. Unifund Corp., 539 F.3d 218, 221 (3d Cir. 2008) (same); Fed. Home Loan Mortg. Corp. v. Lamar, 503 F.3d 504, 509-10 (6th Cir. 2007) (same); United States v. Nat'l Fin. Servs., Inc., 98 F.3d 131, 135-36 (4th Cir. 1996) (same); Bentley v. Great Lakes Collection Bureau, 6 F.3d 60, 62 (2d Cir. 1993) (same); Jeter v. Credit Bureau, Inc., 760 F.2d 1168, 1175 (11th Cir. 1985) (same). The Seventh Circuit, dissatisfied with the majority "least sophisticated consumer" standard, adopted a slight variation in the "unsophisticated consumer” test. Gammon v. GC Servs. Ltd. P’ship, 27 F.3d 1254, 1257 (7th Cir. 1994). The Seventh Circuit was concerned with protecting consumers "of below-average sophistication or intelligence" without tying the standard to "the very last rung on the sophistication ladder." Id. The Seventh Circuit was more interested in ascertaining whether "a person of modest education and limited commercial savvy would be likely to be deceived." Evory, 505 F.3d at 774. With respect to an attorney in collection matters, the Seventh Circuit justified its competent attorney standard by recognizing that an attorney's "sophistication in collection matters would be less than that of the specialist practitioner but much greater than that of the average unsophisticated consumer." Id.

18. See Evory, 505 F.3d at 774-75 (discussing the standard that applies to communications with a consumer's attorney).
} 
This Article concludes with a discussion of the strategies that collectors employ to elicit responses to their demands for payment. Collectors sometimes outline the available options for recovering an outstanding debt; ${ }^{19}$ other times the collector will induce the consumer to pay by threatening certain action that the collector cannot legally take, or does not intend to take. ${ }^{20}$ It is not unusual for a collector to face a consumer's allegations about the amount or legal status of the debt. ${ }^{21}$ The common thread running through these communications is their linguistic formulation, the play on words that leaves the consumer confused and wondering about the collector's message. In some cases, the collector's assurance that it could do something to further collection will have a different impact than saying that it would do something. ${ }^{22}$ In other cases, a collector may create doubt about the character or amount of a debt by not clarifying what it means by the "principal" or the "amount due." ${ }^{23}$ Only by looking to the cases can one make sense of the strategies that collectors employ in their recovery efforts.

19. See Lewis v. ACB Bus. Servs., Inc., 135 F.3d 389, 399 (6th Cir. 1998) (finding that letter offering payment options as part of effort to resolve outstanding debt did not violate statute); Sparks v. Phillips \& Cohen Assocs., 641 F. Supp. 2d 1234, 1249 (S.D. Ala. 2008) (holding that "[m]erely advising the debtor of the agency's options with which to pursue the debt is the sort of truism that is legally insufficient to violate § 1692e”); Mebane v. GC Servs. Ltd. P'ship, 481 F. Supp. 2d 249, 253 (S.D.N.Y. 2007) (holding that offering consumer option to settle debt by payment of $70 \%$ of amount due by cashier's check or money order did not violate statute because the collector did not have to list all acceptable modes of payment); Jackson v. Midland Credit Mgmt., 445 F. Supp. 2d 1015, 1019 (N.D. Ill. 2006) (finding that offering option to settle debt for $50 \%$ of current balance did not violate statute).

20. See Ruth v. Triumph P'ships, 577 F.3d 790, 798-99 (7th Cir. 2009) (holding that inclusion of privacy notice constituted threat to take illegal action to disclose nonpublic information, thus violating § 1692e); Brown v. Card Serv. Ctr., 464 F.3d 450, 455 (3d Cir. 2006) (holding that sending collection letter stating that nonpayment could result in referral to attorney where collector had no intention of doing so violated § 1692e); Schwarm v. Craighead, 552 F. Supp. 2d 1056, 1079 (E.D. Cal. 2008) (finding that collector's threats of legal action or arrest were false because the collector never intended to follow through given that the debtors' files did not meet the criteria for referral).

21. See Miller v. Javitch, Block \& Rathbone, 561 F.3d 588, 593-94 (6th Cir. 2009) (holding that collector's characterization of consumer's credit card debt as a loan did not violate $\S 1692 \mathrm{e}$ ); Hahn v. Triumph P'ships, 557 F.3d 755, 757 (7th Cir. 2009) (stating that the collector did not misrepresent the character of the consumer's debt when it specified the amount of interest due, because that amount comprised interest that accrued after the collector bought the debt and not the interest that was already included when the collector took over the debt).

22. Compare Brown, 464 F.3d at 455 (holding that it would be deceptive for collector to state that it could take legal action that it did not intend to take), with Bingham v. Collection Bureau, Inc. 505 F. Supp. 864, 872 (D.N.D. 1981) (finding that statement that consumer's nonpayment would place account in jeopardy did not violate $\S 1692 \mathrm{e}$ ).

23. See Donohue v. Quick Collect, Inc., 592 F.3d 1027, 1031 (9th Cir. 2010); Wahl v. Midland Credit Mgmt., 556 F.3d 643, 645 (7th Cir. 2009); Hutton v. Law Offices of Collins \& Lamore, 668 F. Supp. 2d 1251, 1255-56 (S.D. Cal. 2009); Mushinsky v. Nelson, Watson \& Assoc., 642 F. Supp. 2d 470, 472 (E.D. Pa. 2009). 
[Vol. 61

\section{FALSE AND MISLEADING REPRESENTATIONS}

\section{A. The Attorney as Collector}

Collectors face daily challenges in recovering debts from defaulting debtors. As a result, collectors frequently plan different strategies to persuade debtors to respond to their demands for payment. If a consumer believes that she is dealing with an attorney collector, she is more likely to respond to a collection notice-and collectors recognize that fact. Many collectors therefore will try to profit from this scenario by using language that suggests an attorney has entered the picture. The only problem is that the FDCPA prohibits a collector from falsely representing that a collection letter comes from an attorney. ${ }^{24}$ The communication can pass the statutory test only if the attorney has personally considered the debtor's case, and not merely lent her name to the collection process. ${ }^{25}$

In Clomon v. Jackson, the signature lines of the collection letters indicated that the attorney was general counsel for NCB Collection Services and bore the attorney's facsimile signature. ${ }^{26}$ The attorney himself made no decisions on individual files and did not approve the letters to the debtor. ${ }^{27}$ The collection letters indicated that the attorney had suggested the collector should take certain measures to collect the "seriously past due account." 28 The letters also assured the consumer that the consumer's account was scheduled for "immediate review and/or further action as deemed appropriate." 29 This language raised questions

24. The statute prohibits "[t]he false representation or implication that any individual is an attorney or that any communication is from an attorney.” 15 U.S.C. § 1692e(3) (2006).

25. See Boyd v. Wexler, 275 F.3d 642, 644 (7th Cir. 2001) (stating that "[a] lawyer who merely rents his letterhead to a collection agency violates the Act”); Clomon v. Jackson, 988 F.2d 1314, 1321 (2d Cir. 1993) (stating that "the use of an attorney's signature implies-at least in the absence of language to the contrary - that the attorney signing the letter formed an opinion about how to manage the case of the debtor to whom the letter was sent”); Miller v. Upton, Cohen \& Slamowitz, 687 F. Supp. 2d 86, 102 (E.D.N.Y. 2009) (stating that "[t]he signing attorney alone is responsible for exercising professional judgment concerning the existence of a valid debt before issuing a debt collection letter"); Palmer v. Stassinos, Nos. C-04-03026 RMW, C-05-02280 RMW, 2009 WL 86705, at *6 (N.D. Cal. Jan. 9, 2009) (stating that "a letter is not 'from' an attorney unless the lawyer, consistent with his professional ethical obligations, exercised direct control and supervision over the process by which the letter was sent”).

26. 988 F.2d 1314, 1317 (2d Cir. 1993).

27. Id.

28. Id. The letters read in part: "After NCB reviews your collection file and previous correspondence sent you, I am suggesting we take the appropriate measures provided under the law to further implement the collection of your seriously past due account.” Id.

29. Id. 
about the attorney's involvement with the collection efforts. ${ }^{30}$ There was no consultation between the attorney and anyone from NCB Collection Services about the details of the debtor's case, and the attorney's facsimile signature merely conveyed the false impression that the letter was from the attorney. ${ }^{31}$ Furthermore, the letterhead indicating "P.D. Jackson, G.C., Attorney-at-Law, Offices of General Counsel,” provided ample evidence that the collector wanted to emphasize the reference to legal representation. ${ }^{32}$ The collector wanted to leave no doubt in the consumer's mind that the communication came from an attorney. ${ }^{33}$

Not all cases are as clean-cut as Clomon, and sometimes a court will find in favor of a collector when countervailing factors neutralize some faint reference to attorney status. In Rumpler $v$. Philips \& Cohen Associates, the collection letter bore the name "Phillips \& Cohen Associates, Ltd.," and made no reference to an attorney. ${ }^{34}$ Nevertheless, the signature line used "Esq." after the officer's name and identified the officer as Executive Vice President. ${ }^{35}$ The court was not impressed by the consumer's attempt to make the "Esq." designation the defining feature of the signature line, finding instead that the officer's title as Executive Vice President neutralized any impression resulting from the use of "Esq." 36 One cannot fault the Rumpler court for finding for the defendant on this occasion, because unlike Clomon, the collection letter made no reference to an attorney, either on the letterhead or the signature line, and nothing in the letter itself feigned legal intervention. ${ }^{37}$

In Rumpler, the consumer lost her battle because she relied on the slender reed of "Esq.," which certainly was not inconsistent with the

30. See id. at 1320. The collector made his impression using certain words. He wanted the consumer to know that he was "suggesting" appropriate measures for collection, that he had "instructions" to pursue collection to the furthest extent he deemed appropriate, and that he had "scheduled" the account for immediate review. Id. at 1320-21. This was precise language, calculated to send a message of the attorney's direct involvement in the ongoing process. Id. at 1321.

31. Id. at 1320.

32. Id.

33. Id. at 1320-21. The court in Clomon made the point that "the use of an attorney's signature on a collection letter implies that the letter is 'from' the attorney who signed it... [and that] the attorney directly controlled or supervised the process through which the letter was sent.” Id. at 1321.

34. 219 F. Supp. 2d 251, 257 (E.D.N.Y. 2002).

35. Id. at 253.

36. Id. at 257. Unlike the situation in Clomon, where the collector identified himself as "P.D. Jackson, Attorney-at-Law, General Counsel," the letter in Rumpler was on the letterhead of Phillips \& Cohen Associates, Ltd., but made no reference to an attorney or law firm. Compare Clomon, 988 F.2d at 1317, with Rumpler, 219 F. Supp. 2d at 257.

37. See Rumpler, 219 F. Supp. 2d at 257. 
functions performed by the collection firm. ${ }^{38}$ If a collection letter falls somewhere on the spectrum between Clomon and Rumpler, it is more difficult for a court to find a false representation of attorney involvement. In Kistner v. Law Offices of Michael P. Margelefsky, LLC, the letterhead referred to law offices, but the letter itself indicated that it came from a collector. $^{39}$ The signature block carried no individual signature; rather, the letter identified the sender as an Account Representative from The Law Offices of Michael P. Margelefsky, LLC. ${ }^{40}$

There was no question that the collection letter lacked clarity. It purported to be from a collector, yet the writer made several references to the law offices of a certain attorney, including guiding the debtor to send her payment there. ${ }^{41}$ Perhaps the defendant anticipated that the term "Account Representative" would neutralize the effect of those references, and thus would convince the court that the debtor could not reasonably get the wrong impression about the letter's origin. ${ }^{42}$

In Kistner, the Sixth Circuit, finding that the case fell somewhere between Clomon and Rumpler, reversed the district court's grant of summary judgment to the collector and remanded the case for a jury to determine whether the collection letter was deceptive and misleading. ${ }^{43}$ Kistner seems much closer to Clomon, as the collector in Kistner left no stone unturned in emphasizing that the letter originated from a law firm. The letter advised that the consumer's account had been referred "to this office," which turned out to be that of attorney Michael P. Margelefsky. ${ }^{44}$ The sender was also keen to point out that the consumer should send payment to Margelefsky's law office. ${ }^{45}$ The defendant attempted to minimize the importance of the law office designation by including the title "Account Representative" in the signature block, even though the letter indicated that the representative resided within the same law

38. Id. Even though "Esq." appeared after the name of the firm's representative on the signature line, the representative signed in his capacity as Executive Vice President and not as an attorney representing the firm. Id. at 253.

39. 518 F.3d 433, 434-35 (6th Cir. 2008).

40. Id. at 435

41. Id. at $434-35$.

42. See id. at 440 (noting that Margelefsky argued at trial that the inclusion of the title “Account Representative” played a significant role in diminishing a reader's confusion).

43. Id. at 440 .

44. Id. at 434. It is significant that the letterhead referred to the "Law Offices of Michael P. Margelefsky, LLC," because that was the place to which the consumer's account was referred. Id. at 435. This would likely give the consumer the impression that he was dealing with an attorney. Id. at 440-41.

45. Id. at 435 . 
office. $^{46}$ Given these repetitive references to a law office, a consumer could hardly be expected to understand that she was dealing with a mere account representative. ${ }^{47}$

In Greene v. Douglas, Knight \& Associates, Inc. (In re Cheaves), the debtor argued that including "\& Associates" in the collector's name implied that the collector was a law firm. ${ }^{48}$ But as the court acknowledged, it would take some level of sophistication for a consumer to conclude that she was dealing with a law firm simply because of the designation "\& Associates." 49 The Greene court rejected the plaintiff's argument that such wording would mislead the least sophisticated consumer. ${ }^{50}$ There was no basis for the plaintiff's assertion that only law firms could have associates, and in any event, such a designation would hardly mislead the least sophisticated consumer. ${ }^{51}$

Another possibly misleading feature of the collection letter was the sender's designation as "Subrogation Specialist.,"52 The court was not convinced that such a title would mislead the least sophisticated consumer into thinking that an attorney had sent the letter, as the court itself admitted that it had no idea what the words Subrogation Specialist meant. ${ }^{53}$ One wonders about the collector's motives because, although it is true that the sender did not say that he was an attorney, subrogation is usually used in a legal context, and the collector surely intended some impact with this term.

46. See id. at 439 (indicating that the trial court accepted the argument that the inclusion of the title "Account Representative" eliminated confusion).

47. Id.

48. 439 B.R. 220, 225 (Bankr. M.D. Fla. 2010). The plaintiff argued that the wording "\& Associates" is "most commonly associated with law firms." Id.

49. Id. at 226 .

50. Id.

51. Id. The court in Zaborac v. Phillips \& Cohen Assocs., Ltd. also found that the use of the word "associates" in the defendant's name did not constitute a false representation that the defendant was an attorney. 330 F. Supp. 2d 962, 969 (N.D. Ill. 2004). The Zaborac court reached this conclusion following the unsophisticated consumer standard adopted by the Seventh Circuit. Id. Because the "\& Associates" title passed the unsophisticated consumer test in Zaborac, it should come as no surprise that it also passed the least sophisticated consumer test applied in Greene. See supra note 17 (explaining the two standards).

52. Greene, 439 B.R. at 226.

53. Id. 
[Vol. 61

\section{B. The Effect of a Disclaimer}

The FDCPA prohibits a collector from misleading a consumer about meaningful attorney involvement. ${ }^{54}$ However, a collector can certainly avoid any ambiguity about an attorney's role in the collection process by using appropriate language to explain the extent of an attorney's involvement in a particular case. In Greco v. Trauner, Cohen \& Thomas, L.L.P., the defendant's collection letter disclaimed as follows: "At this time, no attorney with this firm has personally reviewed the particular circumstances of your account." ${ }^{55}$ The letter left nothing to chance. There was no pretense that the law firm had exercised its legal judgment about the merits of the particular claim, and no language in the letter contradicted the disclaimer of attorney involvement. ${ }^{56}$ The court could find no evidence of a false representation that the communication was from someone acting as an attorney. ${ }^{57}$

The intent of the disclaimer was to clarify for the consumer that the law firm was acting not in a legal capacity when it sent the collection letter, but rather as a collector. ${ }^{58}$ Despite this, the court should have given more weight to the letter's introductory language that identified the defendant as a law partnership retained to collect a debt for its client and to the letterhead, which left no doubt about the firm's identity. ${ }^{59}$ This information preceded the disclaimer, ${ }^{60}$ which in the scheme of things,

\footnotetext{
54. 15 U.S.C. § 1692e (2006).

55. 412 F.3d 360, 361 (2d Cir. 2005).

56. See id. at 365 (stating that defendants' letter could not reasonably be interpreted as misleading). Contrast Greco with the context in Miller v. Wolpoff \& Abramson, where there was no language to counteract the impression that the debtor's case had received an attorney's full attention. See 321 F.3d 292, 296 (2d Cir. 2003) (describing the contents of the letter). The Greco court had the advantage of both the Miller and Clomon formulations about meaningful attorney involvement. It was incumbent upon the attorney to send a proper message to erase doubt about whether she reached the required level of involvement in the transaction as an attorney. The Miller court reflected on the importance of an attorney's signature: "[T] he use of an attorney's signature implies—at least in the absence of language to the contrary - that the attorney signing the letter formed an opinion about how to manage the case of the debtor to whom the letter was sent.” Miller, 321 F.3d at 301 (quoting Clomon v. Jackson, 988 F.2d 1314, 1321 (2d Cir. 1993)).

57. Greco, 412 F.3d at 365.

58. See id. (describing the content of the disclaimer).

59. The first paragraph of the collection letter read as follows:

The firm of Trauner, Cohen \& Thomas is a law partnership representing financial institutions in the area of creditors['] rights. In this regard, this office represents the above named BANK OF AMERICA who has placed this matter, in reference to an Id. at 366 .

original account ... for collection and such action as necessary to protect our client.

60. Id. The disclaimer itself preceded the firm's admonition that its client might consider
} 
may have taken a back seat in the consumer's mind when compared with the firm's specialty of representing collectors.

Although the disclaimer prevailed in Greco, this does not mean that a Greco-type disclaimer will always shield a defendant from liability, because its placement can affect a court's assessment of its impact. For example, the Fifth Circuit in Gonzalez v. Kay found that the consumer had stated a claim for relief where the disclaimer was placed on the back of the collection letter rather than in the body of the letter where the consumer could easily read the entire collection message. ${ }^{61}$ The Fifth Circuit tried in vain to construe this disclaimer-which was conveniently disconnected from the main text-as effective. ${ }^{62}$

In Gonzalez, the parties agreed that none of the attorneys in the Kay Law Firm had reviewed the plaintiff's file or played any role in sending the collection letter. ${ }^{63}$ Nevertheless, one could not ignore the firm's letterhead, which included a statement of the principal's admission to practice in New York and Washington, D.C. ${ }^{64}$ The letter informed the consumer that the law office was handling the consumer's account and instructed him to send payments to the Law Offices of Mitchell N. Kay. ${ }^{65}$ After these references to a law office, the letter finally invited the debtor to "see [the] reverse side for important information." 66 Only by looking at the reverse side could the consumer learn that the collector denied any attorney involvement in the details of the consumer's debt. ${ }^{67}$ It was a

additional remedies if the debtor did not contact the firm. Id.

61. 577 F.3d 600, 606-07 (5th Cir. 2009) (explaining that a consumer reading the main text of the letter might not see the disclaimer on the back).

62. Id. The Fifth Circuit explained its position this way:

The disclaimer on the back of the letter completely contradicted the message on the front of the letter- that the creditor had retained the Kay Law Firm and its lawyers to collect the debt. That is, the disclaimer on the back may not have been effective. There was also ample room on the front of the letter to include this disclaimer so as to clearly articulate to the consumer the nature of the law firm's involvement. Accordingly, this letter falls in that middle ground in which the letter is neither deceptive as a matter of law nor not deceptive as a matter of law. Because the "least sophisticated consumer" reading this letter might be deceived into thinking that a lawyer was involved in the debt collection, Id. at 607 . the district court prematurely dismissed Gonzalez’s complaint.

63. Id. at 602 .

64. Id.

65. Id.

66. Id.

67. The disclaimer read as follows: "At this point in time, no attorney with this firm has personally reviewed the particular circumstances of your account.” Id. The court may have been bothered by the fact that even though there was ample room on the front of the letter to 
disclaimer in the Greco vein, but there was a serious question about whether it commanded the same attention from the least sophisticated consumer as that in Greco.

A disclaimer does not always work, even when it seems that a law firm has done its best to invite a settlement with the debtor. The disclaimer in Lesher v. Law Offices of Mitchell N. Kay, P.C. reassured the debtor that no attorney had personally reviewed the particular circumstances of his account, ${ }^{68}$ the intent being to allay the debtor's fears about any pending litigation. But the law firm had the benefit of its letterhead, which gave its message greater weight. ${ }^{69}$ Undoubtedly, the firm hoped that the disclaimer would neutralize the implication that an attorney had entered the picture with legal remedies in mind if the debtor did not settle the matter. ${ }^{70}$ The distinguishing feature in Lesher was that the disclaimer, like the one in Gonzalez, appeared on the back of the letter and contradicted the collection message on the front. ${ }^{71}$ The Lesher disclaimer was not strong or clear enough to counteract the message on the front that the creditor had retained the law firm to recover the debt. ${ }^{72}$ This was a contradiction that the court would not tolerate. The court apparently was more concerned with the position and the context of the disclaimer. Even though the collection letter contained the statutorily required statement that the communication was from a debt collector, this was not sufficient to nullify the implication that the letter had come from an attorney acting as such.

accommodate the disclaimer, the defendant chose to put it on the back where it might not have the same impact. See id. at 607 (explaining that the letter might deceive the least sophisticated consumer). The Greco disclaimer was effective because it appeared conspicuously on the front of the letter. Greco v. Trauner, Cohen \& Thomas, 412 F.3d 360, 361 (2d Cir. 2005); see also 2 DEE PRidgen \& Richard M. Alderman, Consumer CRedit \& THE LAW § 12:27 (2011-2012 ed.) (stating that "[a] debt collection letter ... may not falsely overstate or imply the amount of attorney involvement in the preparation of the letter"); 1 NAT'L CONSUMER LAW CTR., FAIR DEBT COLLECTION § 5.5.6.3 (7th ed. 2011) (observing that "[i]n the Kay letter, the disclaimer was stuck on the back of the dunning letter following other disclaimers that were in legalese and thus would not be as effective as disclaimers").

68. 650 F.3d 993, 995 (3d Cir. 2011).

69. The letterhead identified the firm as the "Law Offices of Mitchell N. Kay, P.C.” in large letters at the top of the page. Id.

70. See Greco, 412 F.3d at 364-65 (discussing how the construction of a letter bearing a firm's letterhead can imply the firm's level of involvement).

71. See Lesher, 650 F.3d at 1001-02 ("[T]he main ... difference between the cases is whether the letter included a clear, prominent, and conspicuous disclaimer that no lawyer was involved in the debt collection at that time.” (quoting Gonzales, 577 F.3d at 606)).

72. The court noted that the disclaimer contradicted the message on the front of the letter that "the creditor retained a law firm to collect the debt.” Id. at 1003 (footnote omitted). 
Even if a collection letter contains a disclaimer in its text, a court may still find a false representation that a communication is from an attorney. The law firm in Dunn v. Derrick E. McGavic, P.C. must have been confident about the effect of its disclaimer, which it routinely disclosed in the third paragraph of its collection letter. ${ }^{73}$ That disclaimer did not dominate the entire paragraph because the firm included additional language that raised the possibility of judicial remedies if the consumer did not communicate with the law firm. ${ }^{74}$ The letter also threatened immediate suit at the creditor's behest. ${ }^{75}$

The court viewed the disclaimer as not blunting the impact of other language in the letter that emphasized the judicial remedies available if the consumer did not comply with the collector's demands. ${ }^{76}$ The placement of the disclaimer in the body of the collection letter did not insulate the defendant from liability because the letter itself was laden with references to the law firm's role in providing a legal solution to the problem, and the firm wanted to make sure that the consumer would not forget its overall threat of legal action. ${ }^{77}$

The collection letters in Robertson v. Richard J. Boudreau \& Associates, $L L C^{78}$ contained an even stronger message of attorney involvement. Leaving nothing to chance, the law firm sent three letters to the debtor on its letterhead, each containing clear language about the firm's role in the collection process. ${ }^{79}$ The first letter set the stage with the following language: "This law firm has been retained." the type of communication that merely reminded the consumer of an outstanding obligation; instead, it conveyed the impression that the

73. 653 F. Supp. 2d 1109, 1111 (D. Or. 2009).

74. The third paragraph of the collection letter read as follows: "As of this date, no attorney with Derrick E. McGavic, P.C. has personally reviewed the particular circumstances of your account. However, if you do not communicate with this office, the firm's client, Capital One Bank (USA), N.A., may consider judicial remedies to recover the claim from you.” Id.

75. Id.

76. The disclaimer in Dunn, like that in Greco, appeared in the body of the collection letter. Id. The court in Dunn, however, contrasted the five straightforward sentences in Greco with the convoluted nature of the Dunn letter. Id. at 1114. The letter also referred to the balance due as a "claim" rather than a "debt." Id. Overall, the tone of the letter in Dunn compared unfavorably to the simplicity of the Greco message. Id. The emphasis on judicial remedies also concerned the court in Dunn. Id. at 1114-15. The letter sent a false message that an attorney had made some legal assessment of the debt. Id. at 1114 .

77. Id. at $1114-15$.

78. No. C09-1681 BZ, 2009 WL 5108479 (N.D. Cal. Dec. 18, 2009).

79. Id. at $* 2$.

80. Id. (internal quotation marks omitted). 
transaction had reached a level meriting legal intervention. ${ }^{81}$ Two of the firm's letters also emphasized that the firm's review would determine whether a valid legal dispute existed, and still another letter used familiar phrases like "valid legal defense" and "cost of litigation."82

Robertson was another case where the defendant relied on a Grecotype disclaimer to defend against a debtor's allegation that the letters deceptively implied attorney involvement. ${ }^{83}$ The disclaimer seemed perfunctory when considered in context. ${ }^{84}$ The other language in the letters overshadowed the disclaimer because it would lead the least sophisticated consumer to contemplate the possibility of a lawsuit if she did not act promptly to resolve the matter. ${ }^{85}$

Sometimes simplicity is a winning strategy for a collector. In Taylor v. Pinnacle Credit Services, $L L C$, the collection letter not only contained a disclaimer of attorney involvement, but it was also short and concise. ${ }^{86}$ The letter hinted at no claims or litigation and included the usual validation notice that assured the debtor of his right to challenge the debt. $^{87}$ The letter avoided surplusage and did not attempt to embellish

81. See id. (noting that the letters imply impending legal action).

82. Id.

83. The Robertson disclaimer harks back to Greco by stipulating that "no attorney with this firm has personally reviewed the particular circumstances of your account.” Id.

84. See id. (noting that the other content in the letters contradicted and overshadowed the disclaimer).

85. The combination of phrases in the three collection letters convinced the court of a $\S$ 1692e(3) violation. The word "retained" signaled that the attorney was hired to do legal work. Id. Then the second and third letters reminded the consumer that the law firm must determine whether there was a "valid legal dispute." Id. The last letter completed the picture with references to "valid legal defense," “cost of litigation," and "non-litigious resolution.” Id. In the court's view, the language became "increasingly aggressive.” Id. at*3. As a result, it violated § 1692e(5) because the firm's attorneys, not being admitted in California, could not bring the legal action they threatened. Id. Of course, the threat of litigation need not be explicit. See Baker v. G.C. Servs. Corp., 677 F.2d 775, 779 (9th Cir. 1982) (holding that creating the impression that legal action is a real possibility constitutes a threat to take legal action).

86. No. C-10-05164 JCS, 2011 WL 1303430, at*3-4 (N.D. Cal. Apr. 4, 2011). The first paragraph of the letter contained the attorney's substantive demand for payment, and the other material that followed repeated the usual validation notice required by $\S 1692 \mathrm{~g}$ :

This office represents the above named client, PINNACLE CREDIT SERVICES, LLC, who has placed the above-styled matter for collection. This is a demand for full payment because you have had ample time to pay your creditor. Sometimes we can arrange installment payments but you must contact this office for arrangements. At this time, no attorney with this firm has personally reviewed the particular circumstances of your account. Please issue payment to APM financial.

Id. at *3.

87. Id. 
the demand for payment. ${ }^{88}$ In this respect, it was different from the Robertson language in which the threat of legal action overshadowed the disclaimer. ${ }^{89}$ Taylor illustrates what can happen when a collector avoids escalating messages.

\section{The Necessary Connection}

A collector is liable for making a false or misleading representation only if it does so "in connection with the collection of any debt." not always easy to establish such a connection; that question usually comes down to whether the collector would have contacted the consumer in the absence of an outstanding debt. The collector can clarify its purpose for making contact by mentioning the debt in its communication with the consumer. Occasionally, though, the collection letter does not expressly demand payment, and a court must interpret the communication between the collector and the consumer.

In Bailey v. Security Servicing Corp., the mortgage servicer's letter merely reminded the consumers about their obligation to make their payments pursuant to a forbearance agreement and listed the amounts due for the next four payments. ${ }^{91}$ The servicer also reminded the consumers about the consequences of late payments. ${ }^{92}$ The court found that the servicer had made no communication in connection with the collection of a debt because the forbearance agreement was intact and the consumers had missed no payments under the new agreement. ${ }^{93}$ Because there was no default when the servicer sent the letter, the consumers could not show a connection between the letter and debt collection. ${ }^{94}$

Bailey does not require an explicit demand for payment for there to be a communication in connection with collection of a debt, but yet it

\footnotetext{
88. Id.

89. Contrast the succinct demand for payment in Taylor with the increasingly aggressive language in the three letters in Robertson. Compare id., with Robertson, 2009 WL 5108479, at *2.

90. 15 U.S.C. § 1692e (2006).

91. 154 F.3d 384 (7th Cir. 1998). The letter stated as follows:

We wish to work with you on the resolution of your delinquency and will allow you to continue to make the payments remaining under this agreement. However, sending less than the forbearance payment amount and late payment of your monthly installment may render this agreement null and void requiring immediate payment in full of all sums due under the terms of your Note. 
does not prevent a collector from reminding a consumer about the consumer's future payments, instead of her defaulted debts. ${ }^{95}$ It would have been unfortunate had the Bailey court found the servicer liable for a violation, given the circumstances of the servicer's approach to the consumer. The prohibition against unfair tactics in getting the consumer's attention should not prevent a servicer from using its best efforts to convince the consumer of the seriousness of her commitment. The absence of a demand does not always mean that there is no communication in connection with the collection of debt; it was just one of the relevant factors in Bailey that led to the defendant's exoneration. ${ }^{96}$

The search for a connection between a collector's communication and the collection of a debt can prove difficult. It is important to examine not only the context of the communication, but also the relationship between the parties. In Ruth v. Triumph Partnerships, the collector sent a traditional collection letter, but complicated matters by including in the same envelope a privacy notice that expressed the collector's willingness to share information about the debtor with third parties to the extent permitted by law. ${ }^{97}$ The collection letter seemed innocent enough, and the consumer had no complaint about it; however, the privacy notice did concern the consumer, as the collector left open the possibility of sharing the consumer's private information with others

95. The court observed that the letter demanded nothing and gave no impression that any payment under the forbearance agreement was overdue. Id. at 389. The classic collection letter makes a demand for payment. See, e.g., Peter v. GC Servs. L.P., 310 F.3d 344, 347 (5th Cir. 2002) (requiring loan to be paid in full); Bartlett v. Heibl, 128 F.3d 497, 501-02 (7th Cir. 1997) (setting forth example of a collection letter that demands payment but also explains the consumer's validation rights under § 1692g); Grambart v. Global Payments Check Recovery Servs., Inc., No. 10-4399 (DSD/JJK), 2011 WL 124230, at *2 (D. Minn. Jan. 14, 2011) (holding that letter responding to consumer's request for statement of account was not sent in connection with collecting debt); South v. Midwestern Audit Servs., Inc., Civil No. 09-14740, 2010 WL 5089862, at *6 (E.D. Mich. Dec. 8, 2010) (holding that letter notifying consumer that balance was going to be transferred was not sent in connection with collection of debt); Francis v. GMAC Mortg., No. 06-CV-15777DT, 2007 WL 1648884, at *4 (E.D. Mich. June 6, 2007) (finding that letter sent in response to consumer's inquiry was not sent in connection with collection of debt).

96. In Gburek v. Litton Loan Servicing LP, there was no demand for payment. 614 F.3d 380, 386 (7th Cir. 2010). However, the consumer's debt was in default, and one of the defendant's letters offered to discuss foreclosure alternatives and repayment options. Id. Another letter encouraged the consumer to contact the sender to discuss settlement options. See id. Yet another letter the loan servicers sent to a firm requested the firm to collect financial information from the consumer to evaluate foreclosure alternatives. Id. The Seventh Circuit held that these contacts were made in connection with collection of a debt even though there was no specific demand for payment. Id. at 386-87. The court acknowledged that "[t]he absence of a demand for payment was just one of several factors that influenced the outcome in Bailey.” Id. at 385.

97. 577 F.3d 790, 793 (7th Cir. 2009). 
unless the consumer opted out. ${ }^{98}$ The defendants knew that a collector had no right to disclose to third parties any information about a debtor without the debtor's consent ${ }^{99}$ and attempted to minimize their threat of disclosure with the words "to the extent permitted by law."100 Nevertheless, those words implied that a collector could, under some circumstances, disclose private information about the consumer. ${ }^{101}$ Although there was no such leeway under the law, the privacy notice served its purpose by creating the impression that the defendants could share the information that they had obtained during their collection efforts. The only relationship between the consumers and the defendants arose from collection activities, and the privacy notice could not stand in isolation to protect the defendants from the consumers' claims under the FDCPA. ${ }^{102}$ The defendants wanted to enhance their chances of recovering the debt by mixing the two messages-one concerning collection and the other concerning disclosure of private information. The consumers would have read them together as an inducement to act on the debt, rather than suffer the indignity of having their information disclosed to others.

In Bailey, there was no demand for payment, but there was a forbearance agreement preventing any communication with the debtor in connection with the collection of a debt. ${ }^{103}$ Similarly, in Gburek v. Litton Servicing LP, the servicer's communication made no demand for payment, but instead offered the consumer the opportunity to discuss the alternatives to foreclosure and invited the consumer to submit certain financial information for consideration. ${ }^{104}$ The consumer was already in default on her loan when the servicer offered some hope of saving her home, conditioned on her submitting the requested financial

98. See id. (stating the relevant portion of the opt-out notice sent to plaintiffs).

99. See id. at 802 ("[T]he defendants have suggested no set of circumstances under which the FDCPA would have permitted disclosure of the plaintiffs' nonpublic information without their consent.”).

100. Id. at 801-02.

101. Id. at 802. In Smith v. NCO Financial Systems, Inc., the collector indicated to the consumer that it does not disclose information about customers to anyone, "except as permitted by law.” No. 08-CV-5626, 2009 WL 1675078, at *1 (E.D. Pa. June 12, 2009). The court found a violation of $\S 1692$ e because the least sophisticated consumer "is not expected to know there is a law that prevents defendants from performing the disclosures they otherwise indicate they will perform." Id. at *3 (quoting Chapman v. Worldwide Asset Mgmt., L.L.C., No. 04C7625, 2005 WL 818880, at *4 (N.D. Ill. Apr. 6, 2005)) (internal quotation marks omitted).

102. Ruth, 577 F.3d at 799.

103. Bailey v. Sec. Nat'l Servicing Corp., 154 F.3d 384, 388-89 (7th Cir. 1998).

104. 614 F.3d 380, 382-83 (7th Cir. 2010). 
information. ${ }^{105}$ The servicer then turned to a third party to communicate with the plaintiff about the possibilities of a loan workout. ${ }^{106}$ Even though the third-party facilitator made it clear in its communication with the debtor that it had no authority to accept mortgage payments, ${ }^{107}$ it was obvious that its purpose in contacting the debtor was to induce her to come to an agreement accommodating the servicer. ${ }^{108}$ The third party was acting on behalf of the servicer when it sent its letter to the debtor, reinforcing its role in promoting options for settling the debt. ${ }^{109}$

Not every communication between a collector and a consumer will be in connection with the collection of a debt. In Grden v. Leiken Ingber \& Winters, PC, a consumer contacted the collector about the loan balance after the collector had served the consumer with a complaint about the outstanding debt. ${ }^{110}$ The consumer requested written proof about the balance, and the collector sent him a ledger statement listing an incorrect amount. ${ }^{111}$ As a result, the consumer alleged that the collector made a false statement in connection with the collection of a debt. ${ }^{112}$

The consumer in Grden relied on Gburek for support because the collector in both cases had initially communicated with the consumer only because it was trying to collect a debt. ${ }^{113}$ Similarly in Ruth, the collectors claimed a legal right to disclose nonpublic information as a result of their attempt to collect a debt. ${ }^{114}$ However in Grden, the consumer initiated the contact and invited the collector to send written proof of the outstanding balance. ${ }^{115}$ The Grden court saw the consumer's invitation and the collector's subsequent submission of inaccurate ledger figures as independent acts not done in connection with the collection of

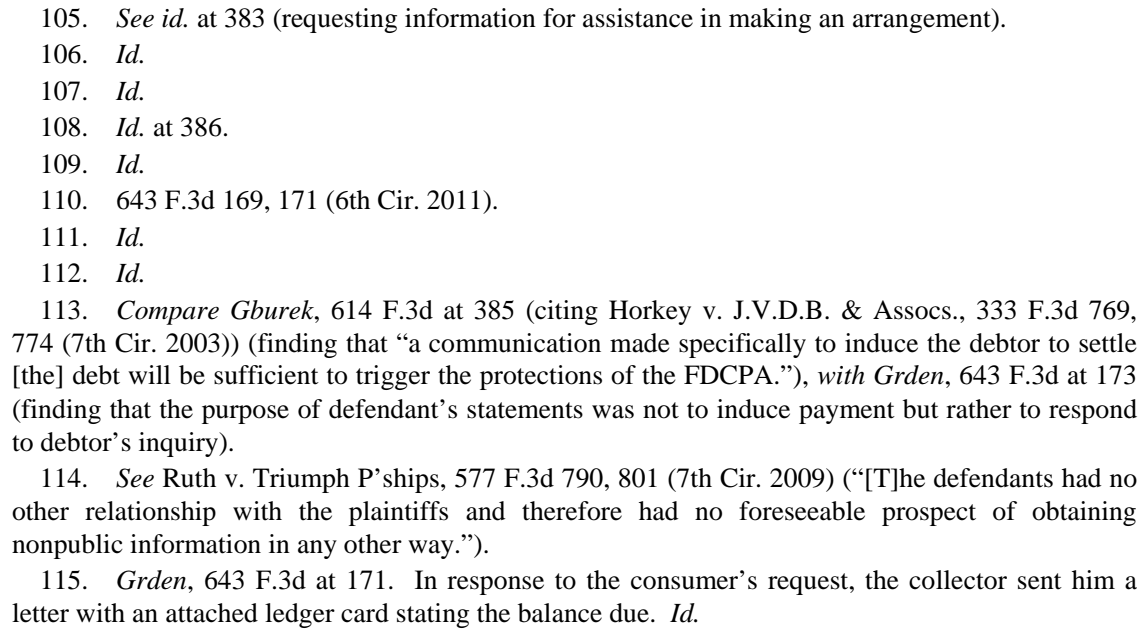

114. See Ruth v. Triumph P'ships, 577 F.3d 790, 801 (7th Cir. 2009) (“[T]he defendants had no other relationship with the plaintiffs and therefore had no foreseeable prospect of obtaining nonpublic information in any other way.”).

115. Grden, 643 F.3d at 171. In response to the consumer's request, the collector sent him a letter with an attached ledger card stating the balance due. Id. 
the debt. ${ }^{116}$ Although it is true that a collector and a consumer will normally communicate only because the former is trying to collect a debt, it does not follow that once they have established a relationship, all subsequent communications must be in connection with collection of the debt. It is entirely possible for the parties to communicate subsequently without the collector treading on collection issues.

Such was the nature of the communication in Francis v. GMAC Mortgage, where the collector merely acknowledged in writing the consumer's denial of the debt, then followed up with a second letter seeking further information about an alleged settlement agreement between the consumer and the previous owner of the debt. ${ }^{117}$ The court noted that the collector's two letters were akin to a "customer service response, rather than a debt collection demand." 118 The letters did not mention anything about payment or collection proceedings, references that one would expect to find in a communication relating to the collection of a debt. ${ }^{119}$ The connection, therefore, must depend on more than a casual conveyance of information relating only incidentally to the debt. ${ }^{120}$ If the drafters of the FDCPA intended to cover all communications between a collector and a consumer, they could easily have done so, and any exchange between the parties would be subject to the statute.

\section{THE IMPACT OF LANGUAGE}

\section{A. Impressing the Debtor}

A collector's challenge is to convince a consumer of the seriousness of the collector's demands without violating the FDCPA. Once the collector creates the impression of attorney involvement, a consumer will

116. See id. at 173 ("The statements were merely a ministerial response to a debtor inquiry, rather than part of a strategy to make payment more likely."). This was reminiscent of the situation in Bailey v. Security National Servicing Corp., where the collection letter simply recited the current status of the debtor's account. 154 F.3d 384, 388-89 (7th Cir. 1998).

117. No. 06-CV-15777-DT, 2007 WL 1648884, at *1 (E.D. Mich. June 6, 2007).

118. Id. at $* 4$.

119. Id.

120. Id. ("Although the letters were sent by a debt collector and, therefore, perhaps remotely related to Plaintiff's alleged debt, the letters were, in context, undisputedly sent in response to an inquiry made by Plaintiff.”). Even so, the second letter related to a potential discharge of the debt, rather than its collection. Id.; see also Salsbury v. Trac A Chec, Inc., 365 F. Supp. 2d 939, 942 (C.D. Ill. 2005) (holding that collector's telephone calls were not in connection with collection of debt when they merely confirmed consumer's legal representation). 
probably react differently to the collection letter. This is why a collector that uses language designed to get the consumer thinking about legal confrontation should consider the impact that such language will have on the least sophisticated consumer. ${ }^{121}$ It is reasonable to raise questions about a collector's intent when the collection letter indicates that it comes from a legal department. ${ }^{122}$ If the legal department has no attorneys, one may wonder whether such a reference is a part of the collector's strategy to convince the consumer that an attorney had a hand in drafting the collection letter. ${ }^{123}$ Such a reference might be misleading to a consumer under $\S 1692 \mathrm{e}(3)$ because the sender ultimately wants the consumer to contemplate the legal ramifications of the communication. The letter does not mute the misleading nature of the message by merely including the statement that the communication is from a collector. ${ }^{124}$ The statute requires such a statement, and there is nothing inconsistent about including the mandatory statement while also extolling one's role as an attorney in the same communication.

In Rosenau v. Unifund Corp., the collector must have been aware of the message that the designation "Legal Department" would send to the consumer. ${ }^{125}$ A consumer could have inferred that the letter had come from an attorney even though the department where it originated contained only nonattorneys. ${ }^{126}$ It seems reasonable that such a department would handle legal matters, and a consumer's musing about

121. See Gonzalez v. Kay, 577 F.3d 600, 607 (5th Cir. 2009) (concluding that a disclaimer of attorney involvement on back of letter may not have been effective and thus district court should not have dismissed claim; letter written on firm letterhead was insufficient to notify the least sophisticated consumer that no attorney had reviewed the case); Rosenau v. Unifund Corp., 539 F.3d 218, 224 (3d Cir. 2008) (finding that the term "Legal Department" does not create the same impression as firm letterhead); Miller v. Upton, Cohen \& Slamowitz, 687 F. Supp. 2d 86, 95 (E.D.N.Y. 2009) (stating that, to the least sophisticated consumer, an attorney's signature on a letter creates the impression that an attorney oversaw and personally reviewed the letter before it was sent).

122. See Rosenau, 539 F.3d at 224 (finding that “the phrase 'Legal Department' could imply to the least sophisticated debtor that a lawyer was involved in drafting or sending the letter”).

123. See id. (reversing the district court's grant of judgment on the pleadings and remanding to the district court to give plaintiff a chance to prove his case).

124. Section $1692 \mathrm{e}(11)$ requires a collection letter to state that the communication is from a collector. 15 U.S.C. § 1692e(11) (2006). That statutory requirement does not necessarily detract from the implication that a letter comes from an attorney acting as such.

125. 539 F.3d 218, 223 (3d Cir. 2008) (taking the view that under the least sophisticated consumer standard, the collection letter could reasonably be read as having two different meanings, one of which was inaccurate).

126. See id. at 224 (noting that "Legal Department” could imply an attorney’s involvement in drafting or sending the letter). 
the role of an attorney in that department is not bizarre under those circumstances.

A collector can get a consumer's attention by using language that suggests some sort of legal review of the consumer's file is taking place. In Adams v. J.C. Christensen \& Associates, questionable language appearing under the heading, "Notice of Legal Review and Settlement Option," provided that the creditor's assignee had prescreened and reviewed the debtor's account "to be forwarded to an Attorney's office licensed in the state of New Jersey." the caption to convey the impression that an attorney had already done the necessary review so that when the debtor received the letter she would understand that the transaction had taken a serious turn. ${ }^{128}$ But the "Legal Review" heading did not tell the whole story, for the text of the letter explained that the debtor's account might be forwarded to an attorney if the debtor did not make the necessary arrangements for payment. ${ }^{129}$ This narrative therefore contemplated future legal review if the collector chose to forward the file to an attorney. ${ }^{130}$ Adams illustrates that a court should not read a caption or heading in isolation, but instead should examine the text of the letter to determine whether an attorney reviewed the letter before it was sent out. ${ }^{131}$ In Adams, the term "Legal Review" did not make the letter false or misleading because it indicated that the creditor's assignee - and not the creditor-had done the prescreening and review, with a view to subsequent attorney involvement if the debtor did not settle her account. ${ }^{132}$

Sometimes it is merely a single word that puts the collector on the defense. In Nelson v. Select Financial Services, Inc., the collector intended to impress the consumer by advising her that her failure to dispute the debt verified the validity of the debt. ${ }^{133}$ The collector intended to justify its future strategy by the consumer's failure to respond to its prior notices, and thus wanted the consumer to know that her

\footnotetext{
127. 777 F. Supp. 2d 1193, 1195 (D. Minn. 2011).

128. See id. at 1196 (noting that this is how the debtor interpreted the letter).

129. Id

130. Id.

131. See id. "Language in a debt-collection letter cannot be viewed in isolation; the letter must be viewed 'as a whole' to determine whether it runs afoul of the FDCPA." Id. (citing Jones v. CBE Grp., Inc., 215 F.R.D. 558, 566 (D. Minn. 2003)); see also Peters v. Gen. Serv. Bureau, Inc., 277 F.3d 1051, 1056 (8th Cir. 2002) (finding that the collector's statement that its only alternative was service by constable was not literally false when considered in context).

132. Adams, 777 F. Supp. 2d at 1196.

133. 430 F. Supp. 2d 455, 456 (E.D. Pa. 2006).
} 
intransigence had confirmed what the collector had claimed all along. ${ }^{134}$ The collector was obviously thinking of $\S 1692 \mathrm{~g}(\mathrm{a})(3)$, which allows the collector to assume that the debt is valid if the consumer does not dispute its validity within thirty days after receiving a validation notice. ${ }^{135}$ But, the statutory assumption that the debt is valid in the absence of the consumer's dispute is a far cry from a statement that the consumer verifies the debt's validity. The statute merely creates a temporary legal fiction that the consumer indeed owes the debt so that the collector can continue its collection efforts with some degree of confidence. ${ }^{136}$

The collection letter in Nelson falsely represented that the consumer's failure to respond would verify the validity of the debt. ${ }^{137}$ The collector sought to give the consumer's inaction more significance than it deserved, for the statute itself provides that the consumer's failure to dispute the validity of the debt should not be construed as a consumer's admission of liability. ${ }^{138}$ The use of the term "verifies" in the collection letter sent a false message that the consumer confirmed or substantiated the validity of the debt, despite saying nothing about it. ${ }^{139}$ It was a message calculated to convince the consumer that she was legally responsible for the debt, even though the statute does not penalize a consumer for silence in the face of the collector's demands. ${ }^{140}$

134. The collection letter stated in part: "You are now being provided notice of our intentions after having been previously offered sufficient opportunity to dispute the validity of this debt." Id.

135. The FDCPA requires a collector to give the consumer a written notice containing certain information. 15 U.S.C. § 1692g(a) (2006). Among other requirements, the collector must provide "a statement that unless the consumer, within thirty days after receipt of the notice, disputes the validity of the debt, or any portion thereof, the debt will be assumed to be valid by the debt collector.” Id. § 1692g(a)(3).

136. See Nelson, 430 F. Supp. 2d at 457 (“[A]ssumed and verifies are not synonyms: assumed conveys that Select pretends or takes for granted that Nelson's debt is valid for purposes of further collection efforts, while 'verifies' conveys that Nelson's inaction for thirty days demonstrates or substantiates the truth of the debt.”); see also Smith v. Hecker, No. Civ.A. 04-5820, 2005 WL 894812, at *4 (E.D. Pa. April 18, 2005) (stating that $\S 1692 \mathrm{~g}(\mathrm{a})(3)$ allows a collector to continue collection activities under "the temporary fiction the debt is correct as stated in the validation notice.”).

137. See Nelson, 430 F. Supp. $2 \mathrm{~d}$ at 456.

138. 15 U.S.C. § $1692 \mathrm{~g}(\mathrm{c})$.

139. See Nelson, 430 F. Supp. 2d at 458.

140. See Gigli v. Palisades Collection, L.L.C., No. 3:CV-06-1428, 2008 WL 3853295, at *6 (M.D. Pa. Aug. 14, 2008) (stating that "a consumer's failure to dispute the validity of a debt will not bar her from defending against a subsequent debt collection lawsuit.”); Velderman v. Midland Credit Mgmt., No. 1:04-CV-269, 2005 WL 2405959, at *7 (W.D. Mich. Sept. 29, 2005) (finding violation where collector misrepresented to consumer that consumer was legally responsible for debt because of failure to dispute debt under § 1692g); Burdett v. Harrah’s Kan. Casino Corp., 294 F. Supp. 2d 1215, 1227 (D. Kan. 2003) (stating that collector was not entitled to summary judgment just because consumers did not dispute the validity of the debt). 
Many collectors couch their demands for payment in terms that leave the consumer unsure about the collector's message. It is in the collector's interest to convince the consumer that her failure to respond to the collector's demands will result in a judgment against the consumer, with ensuing unpleasantness and discomfort. It is not unusual, therefore, for a collector to use language that suggests a lawsuit is imminent and that the consumer can prevent litigation by coming to an agreement with the collector. ${ }^{141}$

There are many variations on this theme. Crossley v. Lieberman ${ }^{142}$ is an early example of a collector's strategy to unsettle the consumer about what lay ahead. There, an attorney sent a letter to the consumer demanding "immediate payment of the full amount of the plaintiff's damages and costs." 143 The letter also identified the creditor as "plaintiff," thereby suggesting that the transaction was already in litigation and that the consumer could conclude matters only by making full payment within one week. ${ }^{144}$ The attorney collector knew that there could be no plaintiff and costs until he had filed a lawsuit. ${ }^{145}$ The attorney also knew that the mere mention of a one-week deadline, combined with the reference to a sheriff's sale, would cause the consumer to think that she had to act quickly to avoid foreclosure, even though the local statute required a lender to give the consumer at least thirty days' notice of any pending action. ${ }^{146}$ The attorney intended to signal that he would sue the consumer if she did not pay within one week. The message was one of inevitability, but it was false and misleading. ${ }^{147}$

141. See Bentley v. Great Lakes Collection Bureau, 6 F.3d 60, 62 (2d Cir. 1993) (finding letter that falsely stated that collector had authority to begin legal proceedings implied legal action was imminent); Pipiles v. Credit Bureau of Lockport, Inc., 886 F.2d 22, 25 (2d Cir. 1989) (holding that "[t]he clear import of the language, taken as a whole, is that some type of legal action has already been or is about to be initiated and can be averted from running its course only by payment.”); Crossley v. Lieberman, 868 F.2d 566, 571 (3d Cir. 1989) (finding letter clearly implied legal action would begin if consumer did not pay within a week).

142. 868 F.2d 566 (3d Cir. 1989).

143. Id. at 567.

144. Id. at 571 .

145. See id. (noting that the collector's "word choice was carefully calculated to suggest to the consumer that she was in the midst of a suit.").

146. The Pennsylvania statute required a collector give at least thirty days' notice to a debtor that the collector intends to foreclose. 41 PA. CONS. STAT. ANN. § 403(a) (West 1988).

147. The attorney also failed to inform the debtor about her right to cure the default. Crossley, 868 F.2d at 571 (citing 41 PA. Const. STAT. ANN. § 403(c)). 
A collection message will usually have greater impact on a consumer if the collector conveys it on law firm letterhead. This is not to say that every collection letter carries an implied threat that the attorney will sue, but an attorney nonetheless knows that ambiguity can convey an empty threat of litigation even when she does not intend to follow through, or in fact cannot, because of legal impediments. ${ }^{148}$ Therefore, when it is unclear whether a collection letter threatens suit, the mere fact that it comes from an attorney makes it more likely to convince a consumer that litigation will ensue. It is not enough, however, for a collection letter to indicate a lawsuit is a mere possibility. ${ }^{149}$ A letter on law firm letterhead, however, may have a stronger impact when it indicates that the firm has been retained to collect a debt and that the consumer must either pay the full amount due or call the law firm to make arrangements. ${ }^{150}$ The message is more powerful still when the collector indicates its desire to make contact about an important legal matter. ${ }^{151}$ The attorney's unique ability to sue lends an attorney's letter the prominence it enjoys in the collection process. ${ }^{152}$ Even when a letter comes from a nonattorney collector, it may instill the same fear if it falsely threatens the intervention of independent counsel, thus motivating a consumer to settle a debt that may not be hers, rather than prolong the agony of the collector's pursuit. ${ }^{153}$

148. The FDCPA specifically forbids "[t]he threat to take any action that cannot legally be taken or that is not intended to be taken.” 15 U.S.C. § 1692e(5) (2006); see Wilhelm v. Credico, 519 F.3d 416, 419 (8th Cir. 2008) (finding that categorical threat to sue violated § 1692e(5) when collector knew that it would not sue any consumers who disputed debt under § 1692g); Gervais v. Riddle \& Assocs., 479 F. Supp. 2d 270, 274-75 (D. Conn. 2007) (holding that threat of litigation violated § 1692 (5) when action on debt was time-barred); Edwards v. McCormick, 136 F. Supp. 2d 795, 805 (S.D. Ohio 2001) (finding that collector violated § 1692e(5) by threatening to take action that he did not intend to take).

149. See Madonna v. Acad. Collection Serv., Inc., No. 3:95CV00875 (AVC), 1997 WL 530101, at *6 (D. Conn. Aug. 12, 1997) (finding that a statement that a collector "may choose to pursue legal action” did not violate $\S 1692 \mathrm{e}(5))$; Riveria v. MAB Collections, Inc., 682 F. Supp. 174, 178 (W.D.N.Y. 1988) (finding that collector's language that "legal action may be necessary" did not violate § 1692e(5)).

150. Miller v. Wolpoff \& Abramson, L.L.P., 321 F.3d 292, 300-01, 304 (2d Cir. 2003); Nielson v. Dickerson, 307 F.3d 623, 635 (7th Cir. 2002); Dunn v. Derrick E. McGavic, P.C., 653 F. Supp. 2d 1109, 1114 (D. Or. 2009).

151. See United States v. Nat'l Fin. Servs., Inc., 98 F.3d 131, 136-38 (4th Cir. 1996) (finding that attorney's letter illegally threatened lawsuit); Gervais, 479 F. Supp. 2d at 273 (noting that the collector's telephone messages indicated that collector was calling about an important legal matter); Russey v. Rankin, 911 F. Supp. 1449, 1454 (D.N.M. 1995) (holding that collection letter threatened litigation when attorney sending it falsely declared he had the legal right to sue).

152. See Gervais, 479 F. Supp. 2d at 276 (emphasizing the effect that the possibility of a lawsuit has on a debtor).

153. See Nat’l Fin. Servs., Inc., 98 F.3d at 138 (finding § 1692e violation where collector falsely 


\section{B. Threat of Imminent Suit}

Sometimes even a masterful mix of language will get a collector in trouble. In Bentley v. Great Lakes Collection Bureau, the collector's first letter informed the consumer that it had instructions "to proceed with whatever legal means [were] necessary to enforce collection."154 A few days later, a second letter advised that the account had been referred to the collector's desk for a decision about enforcing collection. ${ }^{155}$ That second letter concluded with references to post-judgment proceedings that might lead to attachment and garnishment-to say nothing about legal expenses and attorney's fees. ${ }^{156}$ In the ordinary course of events, these letters would have left no doubt in the consumer's mind about the collector's intentions, inasmuch as the collector indicated to the consumer that it had authority to institute legal proceedings against her. $^{157}$

As it turned out in Bentley, the creditor did not confer any such authority on the collector, and therefore the collector created the false impression that it was about to sue the consumer. ${ }^{158}$ The collector alleged that it had unbridled discretion to use all legal means to achieve its objective; ${ }^{159}$ it is understandable that the consumer would sense the imminence of a lawsuit. ${ }^{160}$ According to the collector, there was nothing restraining it from seeking legal remedies against the consumer. ${ }^{161}$ The

\footnotetext{
threatened legal action when it stated that debtor's account would be transferred to an attorney if it remained unpaid); Masuda v. Thomas Richards \& Co., 759 F. Supp. 1456, 1461(C.D. Cal. 1991) (finding that " $[t]$ he representation that independent counsel has been hired may unjustifiably frighten the unsophisticated debtor into paying a debt that he or she does not owe").

154. 6 F.3d 60, 61 (2d Cir. 1993).

155. Id.

156. Id. at $61-62$.

157. Id. at 62 .

158. Id.

159. Id. at 61 .

160. The threat that a suit is imminent is an important element in $\S 1692$ e claims. See Adams v. J.C. Christensen \& Assocs., 777 F. Supp. 2d 1193, 1197 (D. Minn. 2011) (stating that a collection letter that merely indicates that a matter may be referred to an attorney is not a violation); Dewees v. Legal Servicing, LLC, 506 F. Supp. 2d 128, 136 (E.D.N.Y. 2007) (holding that consumers stated a claim where collection letter indicated defendant might file litigation and that the debt was being reviewed for potential litigation); Jenkins v. Union Corp., 999 F. Supp. 1120, 1136 (N.D. Ill. 1998) (stating that "[f]or a collection letter to threaten legal action ...., it must communicate that a lawsuit is not merely a possibility, but that a decision to pursue legal action is either imminent or has already been made.”).

161. See Bentley, 6 F.3d at 61-62 (noting that the collector's letter did not contain any suggestion that there was a limitation on its ability to initiate suit).
} 
so-called referral of the consumer's account to the collector's desk highlighted the collector's message that plans for recovering the debt had reached a critical stage. ${ }^{162}$ The only problem was that the collector had no authority to bring suit, and the collector's characterization of events would have led a consumer to believe that there was no way of avoiding the dire legal consequences flowing from the consumer's delinquency. ${ }^{163}$ As if to soften the blow, the second letter reflected the collector's patience and understanding with the following language: "No legal action has been or is now being taken against you." 164 This was a master stroke; the collector obviously wanted the consumer to understand that the latter presently enjoyed a temporary respite that might end suddenly in light of the collector's existing authority to act as it saw fit. In the final analysis, the language in the two letters proved deceptive. ${ }^{165}$

There is, however, a difference between a collection letter that threatens legal action and one that merely describes legal remedies that may be available to the collector. It is not unusual for a collector to indicate that it will continue its collection activities until the consumer pays her debt. ${ }^{166}$ A consumer may find this strategy objectionable in principle because the FDCPA gives her the right to dispute the debt in writing within thirty days, thus requiring the debt collector to cease its collection activities until it verifies the debt. ${ }^{167}$ In Peter v. GC Services L.P., the consumer claimed that it was misleading for the collector to feign continuous collection activity when it knew that the consumer could interrupt that strategy simply by disputing the debt. ${ }^{168}$ The Fifth Circuit explained, however, that the collector's promise of continued collection activity was not the equivalent of a threat to sue the consumer

\footnotetext{
162. Id. at 62-63.

163. Id. at 63 .

164. Id. at 62 .

165. Id. at 63.

166. Even though a collector must advise a consumer that the consumer has a right to dispute the debt within thirty days, the collector may still continue its collection activities if the consumer does not dispute the debt in writing during that period. 15 U.S.C. § 1692g(b) (2006). A collector can still pursue the consumer because the thirty-day dispute period is not a grace period that prevents the collector from acting. Ellis v. Solomon \& Solomon, P.C., 591 F.3d 130, 135 (2d Cir. 2010); Durkin v. Equifax Check Servs., Inc., 406 F.3d 410, 416 (7th Cir. 2005); Smith v. Computer Credit, Inc., 167 F.3d 1052, 1055 (6th Cir. 1999); see also Mezines, F.T.C. Adv. Op. (March 31, 2000), 2000 WL 34500216 , at *2.

167. 15 U.S.C. § $1692 \mathrm{~g}(\mathrm{~b})$. Although a collector must advise the consumer that it will obtain verification of the debt if the consumer disputes it in writing, id. § $1692 \mathrm{~g}(\mathrm{a})(4)$, the statute does not require the collector to notify the consumer that the consumer's notice of dispute will stop the collector's activities until the collector mails the verification to the consumer.
}

168. 310 F.3d 344, 350 (5th Cir. 2002). 
within the thirty-day dispute period. ${ }^{169}$ There was nothing deceptive about the collector's promise when the collector did not sue. ${ }^{170}$ The collection letter in Peter hardly contemplated legal action by the collector within the thirty-day dispute period, as it referred only to the possibility that the collector would make recommendations to the creditor about pursuing the most effective method for collection. ${ }^{171}$

In the same vein, there is really no threat of legal action if the collector informs the consumer that it has the authority to continue its collection efforts until the consumer pays the debt. The reference to collection efforts in Quamina v. Retrieval Masters Creditors Bureau, Inc. ${ }^{172}$ was similar to the collector's promise in Peter that the debt collector would continue its activities until the consumer paid in full. ${ }^{173}$ It was significant that in both of these cases the collectors were not attorneys, so that when they referred to their collection plans, they contemplated more letters, telephone calls, and communications with credit reporting agencies, rather than a future lawsuit. ${ }^{174}$ This is not to say that they would not ultimately engage attorneys, but that was certainly not their focus in the initial stages of their recovery effort. The

169. Id. The consumer argued that the collection letter was false or misleading under $\S 1692 \mathrm{e}$ because the collector would have had to suspend its collection activities if the consumer disputed the debt under $\S 1692 \mathrm{~g}(\mathrm{a})(4)$, at least until it obtained verification of the debt. Id. However, the statute requires that "[a]ny collection activities and communication during the 30-day period may not overshadow or be inconsistent with the disclosure of the consumer's right to dispute the debt or request the name and address of the original creditor.” 15 U.S.C. $\S 1692 \mathrm{~g}(\mathrm{~b})$. It is this conflict between the consumer's validation rights and the collector's collection rights that has always caused problems. From the consumer's perspective, full payment was the event that would end collection. The same result might ensue if the consumer disputed the debt and the debt collector did not respond to the consumer's notice of dispute. A collector can avoid any ambiguity by providing a specific statement about the suspension of collection activities if the consumer disputes the debt. See, e.g., Lerner v. Foster, 240 F. Supp. 2d 233, 236 (E.D.N.Y. 2003) (stating that "[a]ll efforts to collect this debt will be suspended until we mail any required information to you”).

170. Peter, 310 F.3d at 350 .

171. Id. at 350. Although the consumer in Peter did not succeed in linking the collector's review of the consumer's account to any contradiction of the consumer's validation rights, it is possible to do so in certain circumstances. See Wilhelm v. Credico, Inc., 519 F.3d 416, 419 (8th Cir. 2008) (holding that categorical threat to sue violated $\S 1692 \mathrm{e}$ when collector did not disclose consumer's right to dispute debt); Gilmore v. Account Mgmt., Inc., No. 1:08-CV-1388-JOF-LTW, 2009 WL 2848278, at *6 (N.D. Ga. Apr. 27, 2009) (holding that debt collector violated § 1692e(5) when it threatened to sue even though it failed to verify debt).

172. No. 10-CV-01852 (ERK)(RER), 2011 WL 1099483 (E.D.N.Y. Mar. 22, 2011)

173. The debt collector made its point: "You have apparently chosen to ignore all of our requests for payment. However, be advised that our client has authorized us to continue our collection efforts until you have honored this outstanding obligation.” Id. at *1.

174. See id. at $* 2$ (noting what actions collectors may take). 
least sophisticated consumer therefore would not interpret the promise of collection activity as a threat of imminent suit. ${ }^{175}$

The Bentley language was more definitive in the sense that it emphasized the collector's authority to use "whatever legal means [were] necessary to enforce collection."176 One can see how "legal means" might include legal action, and therefore the Bentley court concluded that this language left the impression that the collector threatened action that it did not intend to take. ${ }^{177}$ The collector could not follow through because it had no authority to sue. ${ }^{178}$ A slight variation in language led to the same result in Berger v. Suburban Credit Corp., in which the collector threatened to take "whatever steps necessary to pursue collection." 179 Although the Berger court recognized the language implied that "the commencement of legal action [was] a possible step," it could find no authority for the collector to take "whatever steps necessary."180 The Berger court therefore found that the collector violated $\S 1692 \mathrm{e}(5)$ because the collector lacked authority to follow through on its threat. ${ }^{181}$

Some collectors thrive on ambiguity. A lack of precision can leave a consumer confused about the collector's plans. When the collector in Brown v. Card Service Center indicated that the consumer's failure to pay in five days "could" result in the file being sent to an attorney for continued collection efforts, the consumer became concerned that the

175. In Spira v. Ashwood Financial, Inc., a debt collector used the following language: "It is our intent to pursue collection of this debt through every means available to us.” 358 F. Supp. 2d 150, 154 (E.D.N.Y. 2005). The court held that the collector did not violate $\S 1692 e(5)$ because the consumer failed to show that the collector did not intend to carry out its threat. Id. at 160. The court recognized that the collector had many options, such as sending more collection letters, requesting payment, placing telephone calls, and forwarding claims to attorneys for litigation. See id. at 160; see also Sparks v. Phillips \& Cohen Assocs., 641 F. Supp. 2d 1234, 1249 (S.D. Ala. 2008) (finding that " $[\mathrm{m}]$ erely advising the debtor of the agency's options with which to pursue the debt is the sort of truism that is legally insufficient to violate § 1692e”).

176. Bentley v. Great Lakes Collection Bureau, 6 F.3d 60, 61 (2d Cir. 1993).

177. See id. at 62 (stating the least sophisticated consumer may interpret the language to mean legal action was “authorized, likely, and imminent”).

178. See id.

179. No. 04 CV 4006 CLP, 2006 WL 2570915, at *2 (E.D.N.Y. Sept. 5, 2006).

180. Id. at $* 7$. The collector did not dispute the consumer's contention that for debts of the size mentioned in Berger, the collector merely sent out notices to or telephoned the debtor. Id. at *7. It was not hard for the court to find a violation of $\S 1692 \mathrm{e}(5)$ because the collector threatened to take action that it did not intend to take. Id. The collector could hardly take "whatever steps necessary," because its authority was limited. Id.; see also Pipiles v. Credit Bureau of Lockport, Inc., 886 F.2d 22, 25 (2d Cir. 1989) (finding violation where collection letter stated that collector would take legal action “As Necessary And Appropriate To Secure Payment In Full”).

181. Berger, 2006 WL 2570915, at *7. 
collector would engage an attorney to increase the pressure. ${ }^{182}$ Despite the tone of the letter, the collector continued its own collection efforts, and the consumer complained that the collector never intended to involve an attorney. ${ }^{183}$

On these facts, the Third Circuit held that the district court erred in dismissing the consumer's complaint because it would be deceptive for the collector to state that it could take an action that it had no intention of taking. ${ }^{184}$ The collector did not say that it would take any particular action, only that it could. ${ }^{185}$ There was a reasonable question as to whether the collector was referring to a mere possibility of a lawsuit or referral to an attorney. If this reference related only to an option available to the collector, the court in Brown might have been persuaded that there was nothing misleading about the collection letter. If, however, the collector never intended to refer these matters to an attorney for further action, there was never truly an option, and the plaintiff had the right to make his case. ${ }^{186}$

Collectors can be as creative as they want to be with their collection message. Nevertheless, they must always be careful not to use language that will mislead or deceive the consumer. In their enthusiasm to draft language that can have two or more different meanings, some collectors

182. 464 F.3d 450 (3d Cir. 2006). The collection letter sent the following message: "You now have five (5) days to make arrangements for payment of this account. Failure on your part to cooperate could result in our forwarding this account to our attorney with directions to continue collection efforts." Id. at 451-52.

183. See id. at 452 (discussing consumer's compliant that the letter was "designed to coerce and intimidate the consumer ... by false threat”(internal quotation marks omitted)).

184. Id. at 455-56. The FTC Official Staff Commentary provides the following guidance:

A debt collector may state that certain action is possible, if it is true that such action is legal and is frequently taken by the collector or creditor with respect to similar debts; however, if the debt collector has reason to know there are facts that make the action unlikely in the particular case, a statement that the action was possible would be misleading.

FTC Official Staff Commentary § 807(5)-3, 53 Fed. Reg. 50,097, 50,106 (Dec. 13, 1988). The Commentary is a guideline intended "to clarify the staff interpretations of the statute." FTC Official Staff Commentary (Introduction), 53 Fed. Reg. at 50,101 (Dec. 13, 1988). It does not bind the FTC or the public because it is not a formal rule or advisory opinion. Id.

185. Brown, 464 F.3d at 451-52.

186. See id. at 456 (discussing that the facts, if proven, entitle Brown to relief); see also United States v. Nat'l Fin. Servs., Inc., 98 F.3d 131, 138 (4th Cir. 1996) (holding that collector had no intention of taking action); Leone v. Ashwood Fin., Inc., 257 F.R.D. 343, 349 (E.D.N.Y. 2009) (holding that threat that collector's action "may" result in suit being filed was deceptive under $\S 1692 \mathrm{e}(5)$ because collector was not authorized to bring suit); Withers v. Eveland, 988 F. Supp. 942, 946 (E.D. Va. 1997) (holding that by threatening to file suit, nonattorney collector violated $\S 1692 \mathrm{e}(5)$ by threatening to take action that he could not legally take or that he did not intend to take). 
run the risk that an inaccuracy will make the letter deceptive. But, after all, that is exactly the collector's objective: leave the consumer with an ambiguity.

In Gonzales v. Arrow Financial Services, $L L C$, the collector tried to collect some debts that were so old that no consumer reporting agency could include them in a consumer report. ${ }^{187}$ The collector offered the consumer a settlement and, as an incentive, volunteered that "if [the collector was] reporting the account, the appropriate credit bureaus [would] be notified that this account [had] been settled." ${ }^{88}$ This language was open to at least two interpretations. If the collector was not reporting the account, there would be no need to report the settlement. ${ }^{189}$ But the language also suggested that there were some circumstances that justified reporting the old delinquencies, and, therefore, the collector could report the good news that the parties had settled the account. ${ }^{190}$ This second interpretation was legally impossible because a collector cannot report the outstanding debt after seven years. ${ }^{191}$ The collector was not about to set the record straight because it wanted to communicate to the consumer that he had everything to gain from a positive report about the settlement. The implication was misleading, but the collector had no interest in clarifying matters for the consumer. The consumer's complaint was justified because one reasonable interpretation of the collection letter was that the collector would take action that was legally impermissible. $^{192}$

The collector in Ruth $v$. Triumph Partnerships engaged in a similar strategy when it included with its demand for payment a notice referring to its right to share private information about the consumer "to the extent permitted by law."

187. 660 F.3d 1055, 1059 (9th Cir. 2011). The Fair Credit Reporting Act provides that a consumer reporting agency may not include in any consumer report "[a]ccounts placed for collection or charged to profit and loss which antedate the report by more than seven years.” 15 U.S.C. § 1681c(a)(4) (2006).

188. Gonzales, 660 F.3d at 1059.

189. Id. at 1063.

190. Id.

191. 15 U.S.C. $§ 1681 c(a)(4)$.

192. Gonzales, 660 F.3d at 1063.

193. 577 F.3d 790, 793 (7th Cir. 2009). The consumer could not prevail simply by alleging that the collector's statements were false. She also had to show that the statements deceived or misled her. Id. at 800. The Seventh Circuit did not require extrinsic evidence of deception in Ruth because it found the collection notice misleading on its face and treated the matter as a question of law. Id. at 801. The court usually requires such extrinsic evidence and treats the matter as an issue of fact if the collector's statements are not plainly misleading or deceptive. See, e.g., Hahn v. Triumph P'ships, 
consumer with the possibilities open to the collector for disclosing the debtor's private information to others. The phrase, "to the extent permitted by law," created an ambiguity intended to induce the debtor to concede. Clearly, the collector threatened action that it either had no intention of taking or could not legally take. ${ }^{194}$

Similarly, the conditional language in Gonzales made the collection letter misleading because it threatened action that the collector could not legally take. ${ }^{195}$ The collector could make a positive report about the debtor's settlement only if it had already filed a negative report about the outstanding debt. ${ }^{196}$ In reality, the collector could not make any kind of report on this stale debt, but the consumer likely would not know about this legal restriction. ${ }^{197}$ Therefore, to avoid the impact of a negative report, the least sophisticated consumer might have succumbed to the collector's demands.

The "if" clause at issue in Gonzalez contributed not only to the misleading nature of the collector's communication, but also to the interpretation that the collector had made a threat to report an old debt to the credit bureaus. ${ }^{198}$ Although not all misleading statements constitute threats to take illegal action, ${ }^{199}$ misleading statements may constitute a violation of $\S 1692 \mathrm{e}(10)$, which prohibits deception. ${ }^{200}$ The Gonzales

557 F.3d 755, 757 (7th Cir. 2009) (discussing need to introduce evidence); Evory v. RJM Acquisitions Funding L.L.C., 505 F.3d 769, 776 (7th Cir. 2007) (stating that evidence is required). Other circuits treat the issue of deception as an issue of law or a mixed question of law and fact. See, e.g., Gonzales, 660 F.3d at 1061 (treating liability as an issue of law); Kistner v. Law Offices of Michael Margelefsky, LLC, 518 F.3d 433, 438 (6th Cir. 2008) (explaining that the determination of whether defendant was a collector was "reduced to a pure question of law"); Peters v. Gen. Serv. Bureau, Inc., 277 F.3d 1051, 1055-56 (8th Cir. 2002) (exploring deception as a mixed question); Terran v. Kaplan, 109 F.3d 1428, 1432-33 (9th Cir. 1997) (discussing the determination of whether collection language contradicts validation notice "does not turn on the credibility of extrinsic evidence”).

194. Ruth, 577 F.3d at 801-02.

195. See Gonzales, 660 F.3d at 1064 (discussing the presence of an implied threat). Section $1692 \mathrm{e}(5)$ forbids a collector from making a "threat to take any action that cannot legally be taken or that is not intended to be taken.” 15 U.S.C. § 1692e(5).

196. Gonzales, 660 F.3d at 1064.

197. See id. at 1064 \& n.7 (emphasizing that the least sophisticated consumer would be unaware that a creditor "could not legally make any report on these obsolete debts.").

198. Id. at 1063.

199. See id. at 1064 n.6 (stating "[a] 'threat' to take legal action that a debt collector has no intention (or ability) to take is necessarily deceptive or misleading, but not all deceptive or misleading statements constitute threats actionable under section [1692]e(5).”).

200. See Ruth v. Triumph P'ships, 577 F.3d 790, 802 (7th Cir. 2009) (finding that a violation of $\S 1692$ (5) is a per se violation of § 1692e(10)); United States v. Nat'l Fin. Servs., Inc., 98 F.3d 131, 138 (4th Cir. 1996) (finding a violation of $\S 1692 \mathrm{e}(5)$ and $\S 1692(10)$ where collector made false 
scenario did not leave much room for the collector to avoid liability on this ground. ${ }^{201}$ It is true that the collector's letter dealt only with the prospects of a positive report in the event of a settlement. ${ }^{202}$ There was no specific reference in the collection letter to a negative report, but the collector left no doubt that the consumer had to settle the matter to improve his credit standing.

\section{The Prospect of Settlement}

Some collectors try to conclude their collection efforts with an offer of settlement that remains outstanding for a limited time. Such a strategy creates the impression that the collector is making a one-time settlement offer to the debtor that will not be revived after the time expires.

The collector in Goswami v. American Collections Enterprise, Inc. knew that it had the authority to settle the consumer's debt at a 30\% discount at any time, yet it indicated in a settlement offer to the consumer that it was available to the consumer "only during the next thirty days." 203 The court recognized that the collector's statement about the time limit was not only untrue, but also that it gave the impression that the settlement offer was a one-time affair that would expire in thirty days. ${ }^{204}$ The word "only" served as a definite restriction in Goswami, leaving little doubt about the collector's intent to bring a close to the negotiations. ${ }^{205}$ Indeed, it was enough to lead the consumer to think that

threats to sue).

201. A collector will always have problems when a collection letter can be interpreted in two different ways, one of which is inaccurate. See Kistner v. Law Offices of Michael P. Margelefsky, LLC, 518 F.3d 433, 441 (6th Cir. 2008) (finding that "the 'more than one reasonable interpretation' standard is applicable to the entirety of $\S 1692 \mathrm{e}$ as a useful tool in analyzing the 'least-sophisticatedconsumer' test”); Brown v. Card Serv. Ctr., 464 F.3d 450, 455 (3d Cir. 2006) (finding that a collection letter is deceptive where "it can be reasonably read to have two or more different meanings, one of which is inaccurate" (quoting Russell v. Equifax A.R.S., 74 F.3d 30, 35 (2d Cir. 1996) (internal quotation marks omitted))); Clomon v. Jackson, 988 F.2d 1314, 1319 (2d Cir. 1993) (stating that courts have found notices deceptive when "they are open to more than one reasonable interpretation”).

202. See Gonzales, 660 F.3d at 1063 (holding that "the phrase 'if we are reporting the account, the appropriate credit bureaus will be notified that this account has been settled' is misleading”).

203. See Goswami v. Am. Collections Enter., Inc., 377 F.3d 488, 492 (5th Cir. 2004) (quoting the collector's letter, "Effective immediately, and only during the next thirty days, will our client agree to settle your outstanding balance" at a discount).

204. See id. at 496 (stating that a collection agency "may not be deceitful in the presentation of that settlement offer").

205. See id. at 495 (observing that "[t]he obvious purpose of the statement was to push Goswami to make a rapid payment to take advantage of the purported limited time offer”). 
time was running out. The problem was that the collector had the authority to give a discount at any time, and so the phrase "only during the next thirty days" conveyed a false message to the consumer, thus creating a deception that violated the FDCPA. ${ }^{206}$ The designation of "only" in Goswami carried the same weight as the "if" that introduced the conditional language in Gonzales. ${ }^{207}$ Moreover, the collector's objectives were the same in both cases: to goad the consumer into action. There is nothing wrong in principle with that strategy, but the collector should not deceive the consumer with a false or misleading scenario.

There is nothing to prevent a collector from making a genuine offer of settlement unaffected by misleading time restrictions or artificial conditions. For instance, when the collector in Dupuy v. Weltman, Wienberg \& Reis Co. made a settlement offer that was "good for fifteen (15) days from the date of [the] letter," the court noted the difference between the one-time offer in Goswami and the offer in Dupuy, which made no reference to the possibility of future offers. ${ }^{208}$ This was a plain indication of the importance of the word "only" to the outcome in Goswami. ${ }^{209}$ The distinction between Goswami and Dupuy is quite reasonable. One would not want to force a collector to make either an open-ended offer or one that, although having an expiration date, announces to the consumer that she can nevertheless expect a better offer in the future.

A collector can clarify a settlement offer by indicating that it has no obligation to renew the current offer. The Seventh Circuit suggested this

206. Id. at 496. The phrase, "only during the next thirty days," distinguishes Goswami from other decisions. For example, in Johnson v. AMO Recoveries, the collection letter stated that "[t]his settlement offer shall be null and void if not received by 09-20-04.” 427 F. Supp. 2d 953, 954 (N.D. Cal 2005). That language set a time limit on that participation offer without saying anything about possible future offers being foreclosed. Id.; see also Gully v. Van Ru Credit Corp., 381 F. Supp. 2d 766, 768 (N.D. Ill. 2005) (holding that settlement offer that "does not expressly or implicitly indicate that no other offer will be made passes muster”); Reade-Alvarez v. Eltman, Eltman \& Cooper, P.C., 369 F. Supp. 2d 353, 361-62 (E.D.N.Y. 2005) (holding that the offer to keep the payment plan open for ten days only did not make the letter false, misleading, or deceptive).

207. See Gonzales, 660 F.3d at 1063.

208. 442 F. Supp. 2d 822, 828-29 (N.D. Cal. 2006) (examining the difference between a onetime offer and an offer of limited duration that is not false within meaning of FDCPA because it is unaccompanied by language implying that it is available one time).

209. See Goswami, 377 F.3d at 495. The collector's settlement language made it appear as though the collector was making "a one-time, take-it-or-leave-it offer" that had only a thirty-day life. Id. This is certainly different from an offer that is valid only if funds are received or secured no later than a certain date. See Hernandez v. AFNI, Inc., 428 F. Supp. 2d 776, 783 (N.D. Ill. 2006). Cf. Prophet v. Myers, 645 F. Supp. 2d 614, 620 (S.D. Tex. 2008) (denying defendant's motion to dismiss consumer claim that settlement offer was misleading because it stipulated that payment must be recovered within thirty days of the date of the collection letter). 
as a safe harbor in Evory v. RJM Acquisitions Funding L.L.C., where it acknowledged that a confusing settlement offer might be deceptive. ${ }^{210}$ The collector's assurance that there is no obligation to renew the offer puts the transaction in proper perspective, for then the consumer will know that she cannot count on another opportunity to settle matters. It is questionable, though, whether a collector should have to go to such lengths to indicate that a settlement offer has a limited life. The collector must avoid the pitfall of pretending that the offer is final when it knows it is not. ${ }^{211}$ But that is quite different from an obligation to set the record straight about the possibilities of renewing the settlement offer. Such a requirement would leave the settlement mechanism in shambles, for then the collector would have to disclose its future plans for dealing with the consumer if the initial overtures do not succeed.

\section{Characterizing the Debt}

A collector violates $\S 1692 \mathrm{e}$ if it misrepresents "the character, amount, or legal status of any debt.”212 One may expect little leeway in misstating the amount of the debt, but Wahl v. Midland Credit Management, Inc. ${ }^{213}$ illustrates that collectors have some breathing space under this requirement. In Wahl, the collector was sued when it broke down the amount due of $\$ 1,181.49$ as constituting the principal balance of $\$ 1,149.09$ and accrued interest of $\$ 32.40 .^{214}$ The consumer complained that the $\$ 1,149.09$ figure included not only the principal amount owed on the credit card to the original creditor, but also interest and late fees charged on that outstanding balance before the account was transferred to the collector. ${ }^{215}$ The consumer argued that the collector's statement was false because it included in the amount due the principal balance owed and the amount of interest that had accrued on the debt before the collector took over the account. ${ }^{216}$

The consumer had a technical point, if one views the principal as an original sum of money owed; ${ }^{217}$ in this case it was the amount obtained

\footnotetext{
210. 505 F.3d 769, 776 (7th Cir. 2007).

211. See Dekoven v. Plaza Assocs., 599 F.3d 578, 579 (7th Cir. 2010); Campuzano-Burgos v. Midland Credit Mgmt., Inc., 550 F.3d 294, 299 (3d Cir. 2008); Goswami, 377 F.3d at 496.

212. 15 U.S.C $§ 1692 \mathrm{e}(2)(\mathrm{A})(2006)$

213. 556 F.3d 643 (7th Cir. 2009).

214. Id. at 644 .

215. Id.

216. Id. at 645 .

217. One dictionary defines "principal" as "a capital sum as distinguished from interest or
} 
through the credit card. But the court viewed the transaction from the collector's perspective, and when the collector took over the debt, the amount was for a global figure that comprised both the original amount obtained through the credit card and the interest that had accumulated because of the consumer's delinquency. ${ }^{218}$ So the collector started out with the figure that was outstanding at the time it took over the account. $^{219}$ The court found that the collection letter would not mislead an unsophisticated consumer because it was not enough that the term "principal balance" was technically false. ${ }^{220}$ An unsophisticated consumer would understand that when the account reached the collector, the principal balance included interest already levied by the creditor.

The Seventh Circuit took the opportunity in Hahn v. Triumph Partnerships $L L C$ to emphasize that a false statement must be material to come under the $\S$ 1692e umbrella, because an immaterial falsehood has no impact on the statutory objective to help consumers make intelligent decisions. ${ }^{221}$ On the facts in Hahn, a consumer would not have been misled in any respect, because the figures did not change. ${ }^{222}$ There, the collector specified the amount it wanted to recover, identifying separately the amount of the debt outstanding when the collector received the account and the collector's interest charges on that amount. $^{223}$ But, in Hahn, the court found the collector's statement to be true when the collector stated the interest due as $\$ 82.64$, although the amount due when the debt was assigned to the collector also included interest on the original debt. ${ }^{224}$ The consumer urged the court to read the

income.” THE CONCISE OXFORD DICTIONARY OF CURRENT ENGLish 948 (8th ed. 1990). Following the consumer's argument, this definition leaves no room for the inclusion of interest. The consumer could have avoided any problem by not using the term "principal." After all, the statute forbids the false representation of the amount of any debt. 15 U.S.C. § 1692e(2)(A).

218. Wahl, 556 F.3d at 644.

219. Id.

220. The court stressed that a technical falsehood was not enough to find that the collector had violated the statute. See id. at 646. The consumer had to show that the statement would mislead an unsophisticated consumer. See id.

221. 557 F.3d 755, 757-58 (7th Cir. 2009).

222. Id. at 757 .

223. Id. at 756. In Muha v. Encore Receivable Mgmt., Inc., the Seventh Circuit found a collector's statement that the consumer's credit card agreement had been revoked to be material. 558 F.3d 623, 630 (7th Cir. 2009). Even under the unsophisticated consumer standard, the court found this statement confusing because the collector's reference to revocation "might have suggested to an unsophisticated consumer that any right he might have to challenge the demand for payment had been extinguished by the revocation of his contract with the issuer, the original creditor." Id. at 629.

224. Hahn, 557 F.3d at 756. 
statement to mean that $\$ 82.64$ was the only interest due. ${ }^{225}$ Had the court accepted that interpretation, however, any inclusion of interest in the amount due before the collector received the account would have made the statement about the interest false. At bottom, the court in Hahn found in favor of the collector not only because the collector's statement was true, but, even if technically false, the statement was immaterial. ${ }^{226}$

The Ninth Circuit in Donohue v. Quick Collect, Inc. followed the Seventh Circuit's materiality requirement when the collector there demanded \$32.89 in interest, a figure which included both preassignment finance charges and interest. ${ }^{227}$ There was no dispute about the total amount owed. The consumer claimed a violation of $\S 1692 \mathrm{e}$ based on the technical incorrectness of the collector's interest designation. ${ }^{228}$ The court was not concerned "with mere technical falsehoods that mislead no one," and in this case the consumer did not dispute the debt. ${ }^{229}$ This illustrates the effect of the materiality requirement.

The Sixth Circuit also lent its voice to the materiality requirement in Miller v. Javitch, Block \& Rathbone, where a consumer complained about certain language in a collector's complaint. ${ }^{230}$ First, the consumer objected to the language in the complaint that referred to "money loaned" by the credit card issuer to the consumer. ${ }^{231}$ The consumer asserted that the credit card issuer did not make any loan to her, and that, therefore, the collector violated the FDCPA when it misrepresented the debt as money loaned. ${ }^{232}$ Although it was true that the bank did not lend any money directly to the consumer, the court noted that the bank paid for goods that the consumer bought with the credit card and made cash

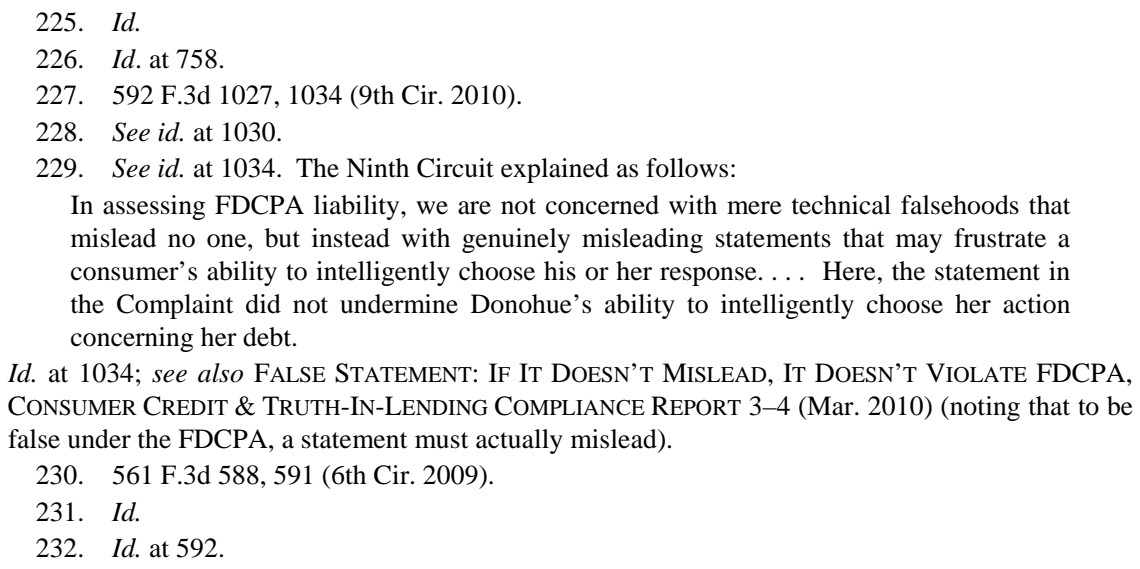


advances to the consumer. ${ }^{233}$ The court found additional support for not treating the "money loaned" phrase as a false representation of the transaction between the bank and the consumer inasmuch as the credit card agreement obligated the consumer to pay the bank all amounts borrowed. ${ }^{234}$ The language could have been clearer, but it was not false because the consumer was ultimately responsible for the amount advanced on her behalf to merchants and others from whom she had bought goods or services. ${ }^{235}$

The consumer also alleged that the collector misled her by using the term "charge card" rather than "credit card."236 It was unfortunate indeed that the consumer framed this as a violation of $\S 1692$; ; the least sophisticated consumer would hardly be led astray by the different terms when there was nothing confusing about the account number or the balance due on the debt. ${ }^{237}$ Such a consumer would hardly pause long enough to assess the difference between the two terms; she would concentrate on the amount she owed. ${ }^{238}$

The consumer's other allegation centered on the claim in the collection complaint that the collector had "acquired, for valuable consideration, all right, title and interest in and to the claim set forth.",239 The consumer contended that this language violated § 1692e(12) because it falsely implied that the original creditor had assigned the debt to an innocent purchaser for value who enjoyed the status of a holder in due course. $^{240}$ It is hard to imagine how the least sophisticated consumer would be misled into considering the concept of a holder in due course because of a complaint's language. Moreover, it would take some

\footnotetext{
233. Id. at 593.

234. Id. See also 1 NAT’L CONSUMER LAW CTR, supra note 67, § 5.5.2.8.

235. See Miller, 561 F.3d at 593.

236. Id. at 595 .

237. Id. The Miller court's characterization of the collector's language elucidated the least sophisticated consumer standard accepted by most courts. The court read the consumer's complaint and evaluated it in a common sense way. Id. The consumer would hardly ponder the difference between a charge card and a credit card in trying to determine the validity of the debt. Id. The Second Circuit said it best in Russell v. Equifax A.R.S.: "[T]he test is how the least sophisticated consumer - one not having the astuteness of a 'Philadelphia lawyer' or even the sophistication of the average, everyday, common consumer-understands the notice he or she receives.” 74 F.3d 30, 34 (2d Cir. 1996).

238. See Miller, 561 F.3d at 595

239. Id.

240. Id. The statute forbids " $[t]$ he false representation or implication that accounts have been
} turned over to innocent purchasers for value.” 15 U.S.C. § 1692e(12) (2006). 
degree of sophistication for a consumer to match such a designation to the forbidden representation in $\S 1692 \mathrm{e}(12){ }^{241}$

\section{THE CHALLENGE OF COMMUNICATION}

\section{A. Communicating with the Debtor's Attorney}

The FDCPA has discouraged collectors from making any false or deceptive representations to consumers during the collection process. If a collector sends a collection letter directly to a consumer, the FDCPA will apply to any ensuing violation. If, however, the collector sends the letter to the consumer's attorney instead, there is judicial disagreement about whether the statute applies. Several circuits agree that the statute regulates communications from a collector to a consumer's attorney; ${ }^{242}$ but, the Ninth Circuit rejects that approach, ruling instead that the statute does not apply to false representations made to an attorney because the attorney protects the consumer. ${ }^{243}$

The exoneration of the collector for a communication sent to an attorney, which would violate the FDCPA if sent directly to a consumer, does not seem to follow from the statutory language. There is nothing in the FDCPA to suggest that the intervention of a debtor's attorney automatically suspends application of the statute, which is intended to control the collector's conduct. It would seem odd for Congress to create this protective framework for consumers only to have it obliterated when the collector diverts its communication to a consumer's attorney.

There is little doubt that what takes place between a collector and a debtor's attorney is in most instances a communication. ${ }^{244}$ The Fourth Circuit recognized a collector's liability for such a communication in Sayyed v. Wolpoff \& Abrahamson, characterizing the collector's contact with the debtor's attorney as an indirect communication with the debtor. $^{245}$ This was not surprising, given the statutory mandate that the

241. See Miller, 561 F.3d at 596 (stating that the least sophisticated consumer has no knowledge of the concept).

242. Allen ex rel. Martin v. LaSalle Bank, N.A., 629 F.3d 364, 368 (3d Cir. 2011); Evory v. RJM Acquisitions Funding L.L.C., 505 F.3d 769, 773 (7th Cir. 2007); Sayyed v. Wolpoff \& Abramson, 485 F.3d 226, 232 (4th Cir. 2007).

243. Guerrero v. RJM Acquisitions LLC, 499 F.3d 926, 929 (9th Cir. 2007) (per curiam).

244. The statute defines communication as "the conveying of information regarding a debt directly or indirectly to any person through any medium.” 15 U.S.C. § 1692a(2).

245. Sayyed, 485 F.3d at 232-33. If the statute did not prevent the collector's direct communication with a represented consumer, then the collector would obviously make a direct 
collector should not communicate with the consumer once the collector knows about the consumer's legal representation. ${ }^{246}$ Put simply, the collector really has no choice about its point of contact once an attorney enters the picture. ${ }^{247}$ The limitation on contacting a represented debtor is part of an elaborate scheme intended to protect the consumer during her most vulnerable moments, and it would be inconsistent with that statutory design to shield a collector from liability once an attorney is on board. ${ }^{248}$

In Guerrero v. RJM Acquisitions LLC, the Ninth Circuit took a different view, holding that a collector could not be liable for a communication sent directly to a debtor's attorney. ${ }^{249}$ The Guerrero court treated the consumer and his attorney as two different people, so that even if the collector ignored its statutory responsibility to the consumer, it had no effect on any communication that the collector had with the attorney. ${ }^{250}$ The court emphasized the distinction between the two relationships by reminding the parties that a collector could not contact a consumer who was represented by an attorney unless the attorney approved that contact. ${ }^{251}$ The court further observed that the collector could not communicate with "any person other than the consumer, his attorney, a consumer reporting agency ...., the creditor, the attorney of the creditor, or the attorney of the debt collector." ${ }^{252}$ In line with this provision, the statute also defines "consumer" as including "the consumer's spouse, parent (if the consumer is a minor), guardian, executor, or administrator.” ${ }^{253}$ This definition provided further support

communication. The inability to make such a communication should not put the violator in a better position when the communication is indirect.

246. See 15 U.S.C. § 1692c(a)(2).

247. Of course, a consumer or his attorney can always give consent for a collector to contact the consumer directly. Id.

248. The Sayyed court relied on Heintz v. Jenkins, 514 U.S. 291, 293 (1995), where the communication was between a debt collection attorney and the consumer's attorney. Sayyed, 485 F.3d at 230. The United States Supreme Court held that the consumer had a cause of action under the FDCPA for statements contained in the collector's letter to the consumer's attorney. Heintz, 514 U.S. at 294.

249. 499 F.3d 926, 939 (9th Cir. 2007) (per curiam).

250. See id. at 935 ("A consumer and his attorney are not one and the same for purposes of the [FDCPA]. They are legally distinct entities, and the Act consequently treats them as such.”).

251. See id. ("[A] debt collector who knows that a consumer has retained counsel regarding the subject debt may contact counsel, but may not generally contact the consumer directly, unless the attorney gives his consent." (footnote omitted)).

252. Id. (emphasis omitted) (quoting 15 U.S.C. § 1692c(b) (2006)).

253. 15 U.S.C. § $1692 c(d)$ (2006). 
for the court's recognition of the consumer and his attorney as two different persons, one of whom - the attorney - the statute did not intend to protect from collectors' deceptive practices. ${ }^{254}$

Some courts view an attorney as an intermediary in the collection process, able to bear the brunt of a cunning collector so that a debtor client does not have to endure a collector's pressure tactics. ${ }^{255}$ It is not clear why there should be a statutory incentive for a collector to pursue a devious collection strategy once an attorney replaces her client as the recipient of the collection letter. Such conduct is justified only if the collector's letter is not considered an indirect communication to the debtor. The statute itself defines communication as "the conveying of information regarding a debt directly or indirectly to any person through any medium."256 Thus, the intervention of an attorney does not transform the contact between the collector and the attorney into some independent liaison having nothing to do with the collection of an outstanding debt. ${ }^{257}$ When a consumer has legal representation, the collector must deal directly with the attorney. ${ }^{258}$ This does not mean that the original transaction between the consumer and the collector takes on

254. See Guerrero, 499 F.3d at 935 (noting that "[t]he statute as a whole ... suggests ... that, when it comes to debt collection matters, lawyers and their debtor clients will be treated differently" because "Congress did not view attorneys as susceptible to the abuses that spurred the need for the legislation ....").

255. See id. ("[I]t appears that Congress viewed attorneys as intermediaries able to bear the brunt of overreaching debt collection practices from which debtors and their loved ones should be protected.”); Kropelnicki v. Siegel, 290 F.3d 118, 127-28 (2d Cir. 2002) ("Where an attorney is interposed as an intermediary between a debt collector and a consumer, we assume the attorney, rather than the FDCPA, will protect the consumer from a debt collector's fraudulent or harassing behavior.”); Zaborac v. Phillips \& Cohen Assocs., 330 F. Supp. 2d 962, 967 n.5 (N.D. Ill. 2004) ("[A] consumer's attorney is quite properly considered an intermediary between the debt collector and the consumer, and as such has his or her own responsibility for protecting the consumer ...." (citation omitted)).

256. 15 U.S.C. § 1692a(2)

257. See Guerrero, 499 F.3d at 943 (Fletcher, J., concurring in part and dissenting in part) (concluding that $\S 1692$ e covers communications between a collector and an attorney representing a debtor because "[t]here is nothing in the text of the FDCPA to indicate that attorneys representing debtors are excluded from the class of third parties to whom a debt collector may not make a false, deceptive, or misleading representation.”); Misleh v. Timothy E. Baxter \& Assocs., 786 F. Supp. 2d 1330, 1335 (E.D. Mich. 2011) (deciding that the FDCPA does not regulate only those communications between a collector and the consumer, but also applies to a collector's communications with a consumer's attorney); Capitol Credit \& Collection Serv. v. Armani, 206 P.3d 1114, 1120 (Or. Ct. App. 2009) (determining that § 1692e of the FDCPA includes communications by the collector to the debtor's attorney).

258. See 15 U.S.C. $\S 1692 \mathrm{c}(\mathrm{a})(2)$ (prohibiting a debt collector from communicating with a consumer in connection with the collection of any debt "if the debt collector knows the consumer is represented by an attorney.”). 
new form, thus granting the collector free rein to do as it pleases. ${ }^{259}$ The prohibition against false or deceptive representations does not disappear just because the collector is no longer addressing the consumer directly. The collector must still obey the statute if it is taking action in connection with the collection of a debt.

In the case of a represented consumer, a collector surely must know that the attorney will share with her client any information she obtains during the collection process. The statute does not purport to protect a deceptive collector whose misbehavior does not reach the debtor directly. The collector must convey its message indirectly to the represented consumer, because the statute forbids the collector from communicating with the consumer if it knows, or can readily ascertain, the attorney's name and address. ${ }^{260}$ This limitation on the collector's direct contact does not provide a sanctuary for the collector, but instead insulates the consumer from interaction with the collector. Section 1692e prohibits a collector from communicating "to any person" false credit information that relates to conduct in connection with the collection of a debt. ${ }^{261}$ This reference to any person obviously includes parties other than the consumer. It is conceivable therefore that a consumer's attorney could be one such person, but that would not make the section inapplicable to the debtor's attorney simply because the attorney is not the consumer. ${ }^{262}$ Therefore, a broad reading of the statute should provide a remedy for the consumer by recognizing a communication as the "conveying of information regarding a debt directly or indirectly to any person through

259. Judge Fletcher gave a good example in Guerrero about the effect of insulating a debt collector from liability with respect to false representations to the consumer's attorney:

[A]ssume that a debt collector sends to a debtor's attorney false documents purporting to verify a debt. In such a case, the attorney might discover the truth and protect the debtor, but she might not. Even if the attorney does discover the truth, she will likely have spent time and money doing so. If $\S 1692$ e does not forbid sending false documents to the debtor's attorney, the debtor will have to pay the attorney's fees and expenses out of his or her own pocket. On the other hand, if § 1692e forbids such communications with the debtor's attorney, the debtor will be able to recover damages and attorney's fees.

Guerrero, 499 F.3d at 945 (Fletcher, J., concurring in part and dissenting in part).

260. See 15 U.S.C. § 1692c(a)(2) (“[A] debt collector may not communicate with a consumer in connection with the collection of any debt if the debt collector knows the consumer is represented by an attorney with respect to such debt and has knowledge of, or can readily ascertain, such attorney's name and address ....”).

261. Id. § 1692e(8).

262. See Quesenberry v. Alliant Law Group., No. 4:09-cv-414, 2010 WL 1189457, at *3 (E.D. Tex. Mar. 5, 2010) (explaining that $\S 1692 \mathrm{a}(2)$ defines "communication" as the conveying of information through any medium); 1 NAT’L CONSUMER LAW CTR., supra note 67, § 5.5.11. 
any medium."263 The statute may reach the collector's conduct either to stop the spread of certain information about the consumer or to prevent other false representations. ${ }^{264}$ In this respect, a consumer's attorney may be either a person or a medium, depending on the context. ${ }^{265}$

The Fourth Circuit clarified in Sayyed that a communication to a debtor's attorney is an indirect communication to the debtor. ${ }^{266}$ This was a reasonable conclusion, given the statutory definition of communication. ${ }^{267}$ However, the court should not have gone further to rely on Heintz $v$. Jenkins, ${ }^{268}$ for although there was attorney-to-attorney contact in that case, the Court only had to consider the question of whether the FDCPA applied to attorneys who collect consumer debts through litigation. ${ }^{269}$ It was a jurisdictional question, therefore, and Heintz did not provide any direct support for the issue considered in Sayyed. When the Third Circuit in Allen ex rel. Martin v. LaSalle Bank, $N$. A., joined the Fourth Circuit in covering a collector's contact with the consumer's attorney, that court noted its disagreement with Sayyed about the relevance of Heintz in this context. ${ }^{270}$ In Allen, the question was whether $\S 1692 \mathrm{f}$ covered the collector's letters to a consumer's attorney containing unauthorized fees, ${ }^{271}$ an issue the Heintz Court did not consider. The Third Circuit noted that it parted with the Fourth Circuit on the Heintz factor, realizing that it could support Sayyed without a Heintz-like diversion. ${ }^{272}$ There was nothing in the statute to direct a

263. 15 U.S.C. § 1692a(2).

264. See Misleh v. Timothy E. Baxter \& Assocs., 786 F. Supp. 2d 1330, 1334 (E.D. Mich. 2011) (explaining that $\S 1692$ forbids collectors from using deceptive, false, or misleading representations or any other unfair or unconscionable means to collect a debt).

265. Evory v. RJM Acquisitions Funding L.L.C., 505 F.3d 769, 773 (7th Cir. 2007).

266. See Sayyed v. Wolpoff \& Abramson, 485 F.3d 226, 232 (4th Cir. 2007) (“A communication to debtor's counsel . . . qualifies as an indirect communication to the debtor.”).

267. 15 U.S.C. § 1692a(2) (defining communication as "the conveying of information regarding a debt directly or indirectly to any person through any medium.”).

268. 514 U.S. 291 (1995).

269. Id. at 292 (identifying the issue as "whether the term 'debt collector' . . applies to a lawyer who 'regularly,' through litigation, tries to collect consumer debts.”).

270. 629 F.3d 364, 368 n.6 (3d Cir. 2011) (explaining the difference between issues addressed in Sayyed and Heintz).

271. Id. at 365 .

272. In Allen the issue was "whether § 1692f(1) governs communications from a debt collector to a consumer's attorney." Id. at 368. In Heintz the Court had to determine whether the FDCPA applied to attorneys trying to collect debts through litigation. See Heintz, 514 U.S. at 292 ("[T]he issue before us is whether the [FDCPA] ... applies to a lawyer who 'regularly' through litigation, tries to collect consumer debts.”). In Guerrero v. RJM Acquisitions $L L C$, the Ninth Circuit, in holding that the FDCPA did not cover a collector's letter to a consumer's lawyer, criticized the Sayyed court for construing Heintz as somehow indirectly acknowledging that the FDCPA covers 
court to ignore an improper communication simply because the collector routed it to the consumer's attorney rather than to the consumer directly. The Allen court felt that absolving the collector of liability in this context would weaken the deterrent effect of the statute's strict liability. ${ }^{273}$

When the Seventh Circuit joined the fray in Evory $v$. RJM Acquisitions Funding, LLC, it sided with Sayyed by recognizing that communications to attorneys are subject to the statute. ${ }^{274}$ In so doing, however, it introduced a new wrinkle that a collector's representation should not be actionable if it would be unlikely to deceive a "competent lawyer."275 This standard lightens the load for the erring collector because the collector no longer has to worry about the unsophisticated consumer who may have succumbed to the collector's deception. One wonders whether the drafters could have intended this result, given Congress's intent to halt deceptive collection practices. It is perplexing to ascertain how the competent lawyer standard applies in a case in which the collector misstates the amount of the debt in its collection letter. ${ }^{276}$ The consumer who has an attorney is, in a sense, in a worse position than one who does not because the represented consumer cannot use her lack of sophistication to hold the collector accountable. The broad definition of communication recognizes that the collector's letter to the consumer's attorney constitutes an indirect advisory statement to the consumer about the state of affairs, and the collector's responsibility for conveying accurate information should not be diminished just because an attorney is the conduit.

communications with a consumer's attorney. 499 F.3d 926, 937-38 (9th Cir. 2006) (per curiam).

273. See Allen, 629 F.3d at 368 ("If an otherwise improper communication would escape FDCPA liability simply because that communication was directed to a consumer's attorney, it would undermine the deterrent effect of strict liability.”).

274. 505 F.3d 769, 773-74 (7th Cir. 2007).

275. Id. at 775 .

276. In Evory, the Seventh Circuit recognized the problem:

A false claim of fact in a dunning letter may be as difficult for a lawyer to see through as a consumer. Suppose the letter misrepresents the unpaid balance of the consumer's debt. The lawyer might be unable to discover the falsity of the representation without an investigation that he might be unable, depending on his client's resources, to undertake. Such a misrepresentation would be actionable whether made to the consumer directly, or indirectly through his lawyer.

Id. at 775; see also Matmanivong v. Unifund CCR Partners, No. 08 CV 6415, 2009 WL 1181529, at *4 (N.D. Ill. Apr. 28, 2009). 
[Vol. 61

\section{B. The Request to Cease Communicating}

The FDCPA imposes an obligation on the collector to suspend its activities until it fulfills the statute's verification requirements. ${ }^{277}$ Suspension is the automatic response when the consumer disputes the debt, but the consumer may simply ask the collector to cease further communication with her without any thought of disputing the debt. ${ }^{278}$ In that event, the collector must heed the consumer's request, although the collector has one last chance to communicate with the consumer about certain remedies that it intends to pursue. ${ }^{279}$

Therefore, the right to halt the collector's communication with the consumer comes at a price: the collector gets a parting shot. A consumer would welcome the good news that the collector is abandoning its collection efforts; the same cannot be said about a recitation of the collector's remedies. The collector's last contact with the consumer about specified remedies is not likely to be polite. It serves merely as an invitation to the collector to emphasize its message, leaving the consumer with a reminder of the alternatives that await her if she does not respond favorably to the collector.

The FTC Official Staff Commentary advises that a collector cannot include a demand for payment in its response to a consumer's request to the collector to cease communicating. ${ }^{280}$ It is possible, however, for a collector to use its last contact to advance its agenda on payment options. ${ }^{281}$ When the collector made such an overture in Lewis v. ACB Business Services, Inc., it found a sympathetic ear in the Sixth Circuit, despite the consumer's contention that the collection letter was a demand for payment couched as a remedy. ${ }^{282}$ It seemed in Lewis that the collector used $\S 1692 c(c)$ as just another stop in the collection process, although the section contemplates merely that the collector can advise the consumer about contemplated remedies. ${ }^{283}$ Once the consumer has

\footnotetext{
277. 15 U.S.C. § 1692g(b) (2006).

278. See id. § 1692c(c) (stating when a collector may no longer communicate with a consumer).

279. Id.

280. FTC Official Staff Commentary § 805(c)-2, 53 Fed. Reg. 50,097, 50,104 (Dec. 13, 1988).

281. The FTC Official Staff Commentary recognizes that the collector's response is limited to the three exceptions covered by $\S 1692$ (c). Id.

282. 135 F.3d 389, 398 (6th Cir. 1998).

283. Section 1692 c(c) provides in pertinent part:

If a consumer notifies a debt collector in writing that the consumer refuses to pay a debt or that the consumer wishes the debt collector to cease further communication with the consumer, the debt collector shall not communicate further with the consumer with
} 
exercised her statutory option to end the collector's contact with her, it is too late for the collector to contact the consumer again under the pretext of offering payment options as a part of the collector's ordinary remedies. ${ }^{284}$ The reference to remedies in $\S 1692$ c(c) suggests that the collector wants to go further to ensure recovery of the outstanding debt because the consumer has closed all other avenues for communication, including the possibility of reaching a settlement. ${ }^{285}$ The statute prevents the collector from making further overtures once the consumer has exercised her option to cease further contact with the collector. It is doubtful that the drafters intended to allow a collector to contrive some mechanism for continuing a dialogue with the consumer-even though a settlement may ensue-when the consumer makes it clear that she wants to end contact. ${ }^{286}$ If the collector is dissatisfied with the consumer's request for silence, it then can inform the consumer about its plans to recover the debt. ${ }^{287}$

respect to such debt, except-

$\ldots$

(2) to notify the consumer that the debt collector or creditor may invoke specified

remedies which are ordinarily invoked by such debt collector or creditor; or

(3) where applicable, to notify the consumer that the debt collector or creditor intends to invoke a specified remedy.

15 U.S.C. $§ 1692 c(c)$.

284. In Lewis, the collection letter provided in pertinent part: "In order to provide you with an opportunity to pay this debt, please select one of the following payment arrangements and enclose payment, or provide me with a number where I can contact you to discuss terms.” Lewis, 135 F.3d at 396. This language is more like an attempt to induce payment than an indication of unilateral action by the collector to collect the debt.

285. If the statute allowed a collector to continue with its offers of various payment plans despite the consumer's request for the collector to cease communications, the consumer would be at the mercy of the collector. The statute would be ineffective in deterring the collector from further contact. Thus, the collector's language need not be abusive in nature for the collector to run afoul of the statute. A consumer may not want to be bothered by a series of payment options, which may be nothing more than a request for payment. 1 NAT'L CONSUMER LAW CTR., supra note 67, § 5.3.8.2.

286. The consumer need not use any special language to make her point. See Bishop v. I.C. Sys., Inc., 713 F. Supp. 2d 1361, 1366 (M.D. Fla. 2010) (finding that the consumer's indication that "[a]ny further correspondence from [the collector] or any other collection agency will be discarded or returned to [the collector unopened" was sufficient to send a message that the consumer wanted the collector to cease communications). A consumer must be careful not to send mixed messages. See Shrestha v. State Credit Adjustment Bureau, Inc., 117 F. Supp. 2d 142, 146 (D. Conn. 2000) (finding no statutory violation when the consumer asked the collector to call while requesting it to cease its collection efforts).

287. See Conklin v. Purcell, Krug \& Haller, No. 1:05-CV-1726, 2007 WL 404047, at *7 (M.D. Pa. Feb. 1, 2007) (finding law firm did not violate statute by sending notice of sheriff's sale, even if consumer did not want further contact from collector), aff'd, 282 F. App'x 193 (3d Cir. 2008); Cohen v. Beachside Two-I Homeowners’ Ass’n, No. 05-706 ADM/JS, 2006 WL 1795140, at *14 (D. Minn. June 29, 2006) (finding no federal statutory violation despite cease communication 
The collector can notify the consumer that it may invoke certain remedies that it ordinarily pursues in trying to collect a debt. ${ }^{288}$ The collector does not have to follow through on its threat, and so one wonders about the reason for allowing a collector to inform a consumer about the possibility of involving the collector's ordinary remedies. ${ }^{289}$ This provision seems to facilitate a collector's last opportunity for pressuring the consumer. It allows a collector to introduce a mere possibility of future action when the consumer has already indicated that she does not want to be bothered. The collector's last-minute notice to the consumer is simply another communication in the collection scheme, and should not override the consumer's directive to the collector. ${ }^{290}$ By the time the consumer notifies the collector that she wants no further communication, the collector has usually been in frequent contact with the consumer. It will come as no surprise to the consumer that the collector gets more aggressive as time goes on. The possibility of invoking the collector's ordinary remedies does not introduce a new element into the collection process. A collector has continuing interest in seeking a remedy, and the statute merely allows a collector to emphasize the possibility of further action, including litigation.

There is a stronger case for allowing a collector to state its intent to invoke a specified remedy even when a collector does not ordinarily pursue such a remedy. It is the collector's intent that makes the difference, for the consumer will know that her notice to the collector to cease communication will trigger the collector's search for a remedy. ${ }^{291}$ After all, if the consumer does not want to hear from the collector anymore, the collector should be able to respond formally to the

directive where attorney returned consumer's check and notified consumer of foreclosure), aff'd as modified, 272 F. App’x 534 (8th Cir. 2008).

288. 15 U.S.C. $\S 1692 c(c)(2)$.

289. Compare id. (allowing collector to notify the consumer that the collector may invoke specified remedies), with id. § 1692(c)(3) (allowing collector to notify the consumer that the collector intends to invoke a specified remedy). The collector can be found in violation if it lacks intent to sue but merely threatens the consumer to prod her into action. See id. § 1692e(5).

290. The statute dictates that "the debt collector shall not communicate further with the consumer" except in three situations. Id. § 1692c(c). The drafters have not given a clue as to why further communication is in the consumer's interest.

291. One authority has stated that "it is much easier to prove a violation of ... section [1692c(c)] when a collector falsely threatens a consumer with an extraordinary action than when it does so with an action that it ordinarily takes in such situations." 1 NAT'L CONSUMER LAW CTR., supra note 67, § 5.3.8.2 (footnote omitted). This is as it should be. A collector should be held to its intent, rather than be able to create discomfort for the consumer through the possible invocation of its ordinary remedies. 
consumer's intransigence. The collector's notice to the consumer about a specified remedy in this context gives the consumer adequate information about the collector's plans. If the collector does not follow through, the consumer will have an independent basis for challenging the genuineness of the collector's threat. ${ }^{292}$

Sometimes a consumer will create some confusion about her request that the collector cease communication. If the consumer gives her directive to the collector and stops there, there is no problem. However, the consumer may seek details of the debt, even while expressing her refusal to pay. This kind of language sends a mixed message, as the collector may view the consumer's refusal as a temporary delay until the collector fulfills its statutory obligation to verify the debt. ${ }^{293}$ It is in the consumer's interest, therefore, to make clear to the collector that she wants no further communication once the collector provides the necessary verification. By doing so, the consumer will leave no doubt about her intent concerning future contacts.

It is an interesting question, though, whether the consumer's notice to the collector to stop communicating with the consumer applies to communications with the consumer's attorney. In Tinsley v. Integrity Financial Partners, Inc., the consumer's attorney could not have been clearer when he responded to the collector with the following language: "[W]e request that you cease all further collection activities and direct all future communications to our office.” ${ }^{\text {"294 }}$ The collector refrained from contacting the consumer and directed its request for payment to the attorney. ${ }^{295}$ The consumer felt that the attorney's letter prevented the collector from continuing its collection contacts with both the consumer and his attorney. ${ }^{296}$ Maybe this was what the consumer had in mind, but the attorney nevertheless invited future communications to his office. ${ }^{297}$ The other possibility is that the consumer may have wanted to stop all

292. See 15 U.S.C. § 1692e(5) (permitting suit for a threat to take any action the collector does not intend to take); id. § 1692e(10) (permitting suit for using deceptive means to collect debt).

293. See Reed v. Global Acceptance Credit Co., No. C-08-01826 RMW, 2008 WL 3330165, at *5 (N.D. Cal. Aug. 12, 2008) (denying summary judgment on consumer’s § 1692c(c) claim where consumer mailed letter disputing the debt and refusing to pay).

294. 634 F.3d 416, 416 (7th Cir. 2011).

295. Id.

296. See id. at 417 .

297. The letter from the consumer's attorney not only requested the collector to stop its collection activities, but also invited the collector to contact the attorney's office in the future. Id. at 416. 
communications to him, but had no intention to restrict communications to his attorney.

The consumer's position in Tinsley was that the attorney was the debtor's agent, so that when the collector continued its correspondence with the attorney, it effectively continued its collection contacts despite the consumer's admonition to stop. ${ }^{298}$ The consumer's discomfort with that possibility made no difference because $\S 1692$ c(a)(2) allows a collector to communicate with the consumer's attorney even though the consumer may object to the collector's direct contact. ${ }^{299}$ It is reasonable, therefore, to read "consumer" and "attorney" as having different meanings in subsection (a)(2), because the language there offers the collector an acceptable alternative for contact when the consumer wants to avoid the collector. Subsection (b) also supports this approach because, without the consumer's consent, a collector cannot communicate with anybody "other than the consumer, his attorney, a consumer reporting agency if otherwise permitted by law, the creditor, the attorney of the creditor, or the attorney of the debt collector." 300 This recognition of the different capacities of a consumer and her attorney simply reflects the understanding that a consumer's attempt to sever her connection with the collector does not simultaneously terminate the collector's authority to communicate with the attorney. ${ }^{301}$ After all, this would run counter to the notion that $\S 1692$ c carves out different roles for consumer and attorney, and that would be inconsistent with the objective of allowing a consumer's attorney to seek a settlement even if the consumer wants to avoid direct confrontation.

\section{CONCLUSION}

There is little doubt that the FDCPA has motivated collectors to reform their collection methods, much to the advantage of consumers in

298. Id. at 417.

299. See 15 U.S.C. § 1692c(a)(2) (2006) (permitting communication where the attorney consents).

300. Id. § 1692c(b).

301. The consumer's attorney invited the collector's communication, thus establishing himself as the future point of contact. Tinsley, 634 F.3d at 416. Section 1692c(a)(2) and (c) work in harmony because once a collector knows about the consumer's legal representation, it cannot communicate with the consumer any more without the consumer's consent. 15 U.S.C. § 1692c(a)(2). Thus, the consumer's invocation of her right to stop the collector from further communication with the consumer does not affect the collector's right to contact the consumer's attorney. See Debt COllector MAy FreEly COMMUNICATE WITH CONSUMER's LAWYER, CONSUMER CREDIT \& TRUTH-IN-LENDING COMPLIANCE REPORT 2-3 (Apr. 2011). 
the marketplace. Nevertheless, there is ample evidence that some collectors still seek to gain advantage from the magical law firm letterhead, while at the same time feigning ignorance of the details of a consumer's file. The accommodation of a disclaimer in this context only sends a conflicting message to the consumer about an attorney's role in the transaction. The disclaimer's function is to tell the consumer that the collector is not functioning in the capacity of an attorney, but a communication on law firm letterhead sends a powerful message that the consumer should be thinking about its legal ramifications. When the first paragraph of a collection letter indicates that the collector is a law firm "representing financial institutions in the area of creditors rights," 302 a consumer cannot be blamed for believing that the firm is involved in a legal capacity, despite the reassurance in the letter's subsequent language that no attorney has reviewed the particular circumstances of the consumer's account. This Article submits that courts must not allow a simple disclaimer to override the overall indicators of an attorney's involvement, for an attorney collector must realize that her status as an attorney drives home the message that the consumer is now in the legal arena. $^{303}$ If an attorney wants to avoid any ambiguity about her role, she has the obligation to make any disclaimer conspicuous and not leave the collection letter subject to more than one interpretation. ${ }^{304}$

Although there is some disagreement in the courts about whether the FDCPA should regulate communications between a collector and a consumer's attorney, this Article submits that those courts supporting an exemption for such communications provide an incentive for a collector to avoid the statutory restrictions. Although the statute requires a collector to communicate with a consumer's attorney once there is evidence that the attorney has entered the picture, it does not give the collector free rein to do as it pleases in that event. There is much to be said for recognizing that indirect contact with the attorney constitutes a communication under the statute. There is no evidence to suggest that the statute gives less protection to a represented consumer. It would hardly be acceptable for such a consumer to be disadvantaged compared

\footnotetext{
302. Lesher v. Law Offices of Mitchell N. Kay, PC, 650 F.3d 993, 1000, 1003 (3d Cir. 2011).

303. Id. at 1002-03.

304. See Gonzalez v. Kay, 577 F.3d 600, 607 (5th Cir. 2009) (stating that attorney must state clearly and conspicuously that she is acting solely as a collector when sending a collection letter); Dunn v. Derrick E. McGavic, P.C., 653 F. Supp. 2d 1109, 1114 (D. Or. 2009) (finding violation where disclaimer was obscured by rest of letter); Smith v. Harrison, No. 07-4255 (WHW), 2008 WL 2704825 , at *4 (D.N.J. July 7, 2008) (finding violation where letter's ambiguity left open multiple interpretations, one of which was unlawful).
} 
[Vol. 61

to an unrepresented consumer. The distinction between the two types leads to a query about the real meaning of communication under the statute and raises doubts about whether a collector's conduct avoids the collection label simply because the collector is not in direct contact with the consumer. 